\title{
RELATOS DE PESQUISAS \\ GESTÃO EMPRESARIAL: UM ESTUDO SOBRE O MICROEMPREENDEDOR INDIVIDUAL DO SETOR DE COMÉRCIO DO MUNICÍPIO DE SÃO MATEUS-ES
}

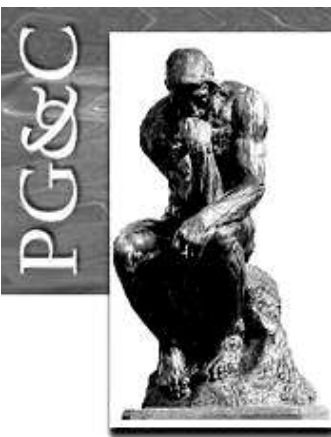

\author{
José Geraldo Ferreira da Silva \\ Doutor em Engenharia Agrícola pela Universidade Federal de Viçosa, \\ Brasil. Professor da Faculdade Vale do Cricaré, Brasil. \\ E-mail: igeraldo525@gmail.com \\ Vivian Hannah Mota de Andrade \\ Mestranda em Ciência, Tecnologia e Educação pela Faculdade Vale do \\ Cricaré, Brasil. \\ E-mail: vivian.hannah18@hotmail.com
}

\begin{abstract}
Resumo
O comércio é um dos setores que mais contribui à economia do município de São Mateus e uma grande quantidade de micro e pequenas empresas é notada, destacando-se o Microempreendedor Individual (MEI). Diante disto, esta investigação tem o propósito de contribuir com informações que possam auxiliar a gestão empresarial dos MEls do setor de comércio em São Mateus; traçando o perfil desses sujeitos jurídicos, identificando suas principais necessidades gerenciais e sua percepção acerca das instituições de apoio presentes no município; e possibilitar soluções para o enfrentamento das necessidades identificadas. Para isso, foi realizada uma pesquisa de campo no município, entre os meses de julho e agosto do ano de 2019, aplicando-se questionários a um grupo de 92 MEls comerciantes. Percebeu-se que os MEIs necessitam de auxílio na abertura do negócio para que se mantenham sustentáveis e tenham menos dificuldades na condução e gestão do negócio. Diante disso, recomendase ao Governo e às instituições de apoio ao empreendedorismo que trabalhem para alcançar esse público, sugere-se ainda que os MEls busquem adquirir conhecimento para aprimorar seus negócios.
\end{abstract}

Palavras-chave: Microempreendedor Individual. Comércio. Gestão empresarial.

\section{BUSINESS MANAGEMENT: A STUDY ON THE INDIVIDUAL MICROENTREPRENEUR OF THE COMMERCE SECTOR IN THE MUNICIPALITY OF SÃO MATEUS-ES}

\begin{abstract}
Trade is one of the sectors that most contributes to the economy of the municipality of São Mateus and a large number of micro and small companies is noted, with emphasis on the Individual Microentrepreneur (MEI). In view of this, this investigation has the purpose of contributing with information that can help the business management of the MEls of the commerce sector in São Mateus; tracing the profile of these legal subjects, identifying their main managerial needs and their perception about the support institutions present in the municipality; and enabling solutions to address identified needs. For this, a field survey was carried out in the municipality, between the months of July and August of the year 2019, applying questionnaires to a group of 92 merchant MEIs. It was noticed that the MEIs need assistance in opening the business so that they remain sustainable and have less difficulties in conducting and managing the business. In view of this, it is recommended that the Government and institutions that support entrepreneurship work to reach this audience, it is also suggested that MEls seek to acquire knowledge to improve their business.
\end{abstract}

Keywords: Individual Microentrepreneur. Trade. Business management.

Perspectivas em Gestão \& Conhecimento, João Pessoa, v. 11, n. 2, p. 59-84, maio/ago. 2021. DOI: http://dx.doi.org/10.22478/ufpb.2236-417X.2021v11n2.54968

http://periodicos.ufpb.br/ojs2/index.php/pgc. ISSN: 2236-417X. Publicação sob Licença (cc) EY-NC-ND 


\section{INTRODUÇÃO}

Os Microempreendedores Individuais (MEI) encontram-se em grande número no país, é notória a sua importância no meio empresarial e no fortalecimento do mercado de trabalho para o desenvolvimento socioeconômico do país. Segundo o Serviço Brasileiro de Apoio às Micro e Pequenas Empresas (SEBRAE), até janeiro de 2019, o número de MEls representa $63,20 \%$ do total de empresas optantes pelo Simples Nacional (Regime Especial Unificado de Arrecadação de Tributos e Contribuições devidos pelas Microempresas e Empresas de Pequeno Porte), sendo 7,9 milhões de MEls e 4,6 milhões de Microempresas e Empresas de Pequeno Porte (SEBRAE, 2019a).

Para incentivar e dar suporte aos pequenos negócios foi sancionada a Lei Complementar Federal 123/2006, a qual garante o tratamento diferenciado e favorecido e, posteriormente, em 2008, houve uma alteração nesta lei para enquadrar a figura do MEI (LCF 123/2006).

A legislação supracitada acarretou no aumento da empregabilidade e da formalização dos negócios, diminuindo o número de pessoas que trabalham na informalidade; e também colaborou para a arrecadação tributária, contribuindo consequentemente para a economia do país. A formalização do MEl é uma oportunidade de profissionalização das atividades, que gera aquecimento da economia e principalmente o exercício da cidadania destes profissionais (MARIA; SOUZA, 2013).

O SEBRAE (2016a), em pesquisa realizada entre 2010 e 2014, retrata que a taxa de sobrevivência das empresas com até 2 anos aumentou de $54 \%$ para $77 \%$. Esse número se deve em consequência do registro oficial dos MEls, o qual teve início em 2009. A pesquisa ainda aponta que a causa da mortalidade de empresas no país não se atribui a um único fator, mas a um conjunto deles: a situação do empresário antes da abertura, o planejamento dos negócios, a capacitação em gestão empresarial e a gestão do negócio em si.

Borges e Oliveira (2014) também corroboram esse entendimento ao concluírem que um conjunto de fatores influenciam o fechamento de micro e pequenas empresas, assim como a acumulação desses fatores aumentam as chances de mortalidade. Destacam também, que o cenário econômico e as políticas públicas de apoio às MPEs tiveram uma evolução positiva, e há maior procura de empreendedores por capacitações, bem como informações antes da abertura do negócio. Entretanto, não houve melhora em relação à gestão empresarial, exigindo maior atenção nesse fator para evitar um aumento na taxa de mortalidade das MPEs.

Diante disto, o presente trabalho se faz necessário por estudar as principais necessidades gerenciais do Microempreendedor Individual, mais estritamente do setor de comércio no município de São Mateus-ES. Com o intuito de ofertar à população mateense, e à região Norte do Espírito Santo, a identificação dos órgãos de apoio presentes no município, bem como o tipo de auxílio que realizam com o Microempreendedor Individual; a supracitada investigação também almeja ser divulgadora de informações que possam favorecer a capacitação dos futuros donos de pequenos negócios. Ademais, oferece a oportunidade de conhecer o perfil do empresariado mateense, neste caso o Microempreendedor Individual, o qual possui um importante papel na economia da cidade e adjacências.

Em suma, trata-se de uma pesquisa importante para auxiliar e aprimorar o trabalho das entidades de apoio aos pequenos negócios, conhecendo as necessidades dos Microempreendedores Individuais do município e, consequentemente, podendo ajudar no desenvolvimento sustentável dessas empresas. Isto posto, questiona-se: Qual é o perfil do Microempreendedor Individual do ramo comercial do município de São Mateus-ES e suas necessidades em relação à gestão empresarial?

Perspectivas em Gestão \& Conhecimento, João Pessoa, v. 11, n. 2, p. 59-84, maio/ago. 2021. 
A partir desse questionamento, o trabalho teve como objetivo geral contribuir com informações que possam auxiliar a gestão empresarial dos Microempreendedores Individuais do setor de comércio no município de São Mateus, assim como traçar o perfil do Microempreendedor Individual, do ramo de comércio, no município de São Mateus, suas principais necessidades gerenciais e sua percepção acerca das instituições de apoio presentes nessa localidade - a fim de possibilitar soluções para o enfrentamento das necessidades identificadas.

\section{PERCURSO METODOLÓGICO}

Tendo em vista os objetivos anteriormente citados, os movimentos práticos aqui se deram por meio de pesquisa de campo para possível levantamento de dado. Justifica-se esse procedimento teórico-metodológico a partir da voz de Gil (2008, p. 55):

As pesquisas desse tipo se caracterizam pela interrogação direta das pessoas cujo comportamento se deseja conhecer. Basicamente, procede-se à solicitação de informações a um grupo significativo de pessoas acerca do problema estudado para em seguida, mediante análise quantitativa, obter as conclusões correspondentes dos dados coletados.

Nesse sentido, para realização da pesquisa junto à população de Microempreendedores Individuais no ramo de comércio municipal foi utilizado o questionário como técnica de pesquisa para medir as variáveis.

Os questionários podem ser elaborados por escrito para serem aplicados aos respondentes, sendo autoaplicados, ou seja, respondidos por escrito pelo próprio respondente. Também podem ser aplicados de forma oral pelo pesquisador, sendo designados como questionários aplicados com entrevista ou formulários (GIL, 2008).

Nesta pesquisa o questionário foi aplicado nas duas formas, de forma oral ou escrita, a depender da pessoa que o respondeu, de acordo com o nível de escolaridade, interpretação das perguntas, disponibilidade de tempo e outras circunstâncias. Para essa execução, participou a própria pesquisadora e foram contratados três entrevistadores, os quais receberam treinamento e material para a realização do trabalho de coleta de dados de maneira eficiente.

O questionário e as variáveis estudadas, conforme apresentadas nos quadros 1,2 e 3 a seguir, foram criados tendo como base os estudos do Global Entrepreneurship Monitor (GEM, 2017) - que retrata as características dos empreendedores brasileiros e seus negócios; e o do SEBRAE (2017) - que descreve o perfil do Microempreendedor Individual. Ambos os estudos utilizaram questionário para realizar os levantamentos.

Ainda conforme os objetivos da pesquisa, o questionário foi dividido em três partes: a) a primeira busca traçar o perfil do Microempreendedor Individual do setor comercial do município, conforme Quadro 1 ; b) a segunda para identificar as principais necessidades na gestão desses pequenos negócios, de acordo com o Quadro 2; c) e a terceira para identificar o conhecimento dos MEls quanto às instituições de apoio presentes no município - como é possível analisar no Quadro 3.

Quadro 1 - Perfil socioeconômico do Microempreendedor Individual

\begin{tabular}{l|l}
\hline 1. Faixa etária: & 2. Sexo: \\
( ) 18 a 29 anos & ( ) Feminino \\
( ) 30 a 39 anos & \\
( ) 40 a 49 anos &
\end{tabular}

Perspectivas em Gestão \& Conhecimento, João Pessoa, v. 11, n. 2, p. 59-84, maio/ago. 2021. 


\begin{tabular}{|c|c|}
\hline $\begin{array}{l}\text { ( ) } 50 \text { a } 59 \text { anos } \\
\text { ( ) } 60 \text { anos ou mais }\end{array}$ & \\
\hline \multicolumn{2}{|l|}{$\begin{array}{l}\text { 3. Grau de escolaridade: } \\
\text { ( ) Pós-graduação completa ou não } \\
\text { ( ) Ensino superior completo } \\
\text { ( ) Ensino médio completo } \\
\text { ( ) Ensino fundamental completo } \\
\text { ( ) Não tive oportunidade de estudar }\end{array}$} \\
\hline $\begin{array}{l}\text { 4. Faturamento médio mensal do } \\
\text { negócio: } \\
\text { ( ) Até } 1 \text { salário mínimo (até } R \$ 998,00 \text { ) } \\
\text { ( ) De } 1 \text { a } 2 \text { salários mínimos (de } R \$ 998,00 \\
\text { a } R \$ 1.996,00 \text { ) } \\
\text { ( ) De } 2 \text { a } 3 \text { salários mínimos (de } \\
R \$ 1.996,00 \text { a } R \$ 2.994,00 \text { ) } \\
\text { ( ) De } 3 \text { a } 4 \text { salários mínimos (de } \\
R \$ 2.994,00 \text { a } R \$ 3.992,00 \text { ) } \\
\text { ( ) De } 4 \text { a } 5 \text { salários mínimos (de } \\
R \$ 3.992,00 \text { a } R \$ 4.990,00 \text { ) } \\
\text { ( ) De } 5 \text { a } 6 \text { salários mínimos (de } \\
R \$ 4.990,00 \text { a } R \$ 5.988,00 \text { ) } \\
\text { ( ) De } 6 \text { a } 7 \text { salários mínimos (de } \\
R \$ 5.988,00 \text { a } R \$ 6.986,00 \text { ) } \\
\text { ( ) Mais de } 7 \text { salários mínimos (Mais de } \\
R \$ 6.986,00 \text { ) }\end{array}$ & $\begin{array}{l}\text { 5. Renda média mensal de outra fonte que não seja } \\
\text { o MEl: } \\
\text { ( ) Não possuo } \\
\text { ( ) Até } 1 \text { salário mínimo (até } R \$ 998,00 \text { ) } \\
\text { ( ) De } 1 \text { a } 2 \text { salários mínimos (de } R \$ 998,00 \text { a } \\
R \$ 1.996,00 \text { ) } \\
\text { ( ) De } 2 \text { a } 3 \text { salários mínimos (de } R \$ 1.996,00 \text { a } \\
R \$ 2.994,00 \text { ) } \\
\text { ( ) De } 3 \text { a } 4 \text { salários mínimos (de } R \$ 2.994,00 \text { a } \\
R \$ 3.992,00 \text { ) } \\
\text { ( ) De } 4 \text { a } 5 \text { salários mínimos (de } R \$ 3.992,00 \text { a } \\
R \$ 4.990,00 \text { ) } \\
\text { ( ) De } 5 \text { a } 6 \text { salários mínimos (de } R \$ 4.990,00 \text { a } \\
R \$ 5.988,00 \text { ) } \\
\text { ( ) De } 6 \text { a } 7 \text { salários mínimos (de } R \$ 5.988,00 \text { a } \\
R \$ 6.986,00 \text { ) } \\
\text { ( ) Mais de } 7 \text { salários mínimos (Mais de } R \$ 6.986,00 \text { ) }\end{array}$ \\
\hline $\begin{array}{l}\text { 6. Há quanto tempo você atua como MEI? } \\
\text { ( ) Menos de um ano } \\
\text { ( ) Entre } 1 \text { e } 2 \text { anos } \\
\text { ( ) Entre } 3 \text { e } 4 \text { anos } \\
\text { ( ) Entre } 5 \text { e } 6 \text { anos } \\
\text { ( ) Há mais de } 6 \text { anos }\end{array}$ & \\
\hline
\end{tabular}

Fonte: Elaborado pelos autores

Quadro 2-Gestão do Negócio
7. Você se tornou um microempreendedor por que motivo?
( ) Não havia outra oportunidade de trabalho
( ) Vi como sendo um boa oportunidade de crescimento profissional
( ) O mercado de trabalho que atendo me direcionou para este ramo
( ) Para sair da informalidade
( ) Desejava ter meu próprio negócio
( ) Outro

\begin{tabular}{|c|c|}
\hline $\begin{array}{l}\text { 8. Qual foi a principal dificuldade para abrir } \\
\text { o seu negócio? } \\
\text { ( ) Nenhuma } \\
\text { ( ) Elaborar o planejamento do negócio } \\
\text { ( ) A falta de experiência do ramo } \\
\text { ( ) O desconhecimento do mercado } \\
\text { ( ) Burocracia para formalização do negócio } \\
\text { ( ) Falta de capital } \\
\text { ( ) Outra }\end{array}$ & $\begin{array}{l}\text { 9. Na sua opinião foi difícil oficializar o seu } \\
\text { negócio? } \\
\text { ( ) Não tive nenhuma dificuldade } \\
\text { ( ) Tive pouca dificuldade } \\
\text { ( ) Tive dificuldade } \\
\text { ( ) tive muita dificuldade } \\
\text { ( ) Tive dificuldade extrema }\end{array}$ \\
\hline $\begin{array}{l}\text { 10. Quais as três maiores dificuldades na } \\
\text { condução do seu negócio? } \\
\text { ( ) Nenhuma } \\
\text { ( ) Falta de planejamento/organização }\end{array}$ & $\begin{array}{l}\text { 11. Quais as três maiores dificuldades } \\
\text { encontradas na gestão do seu negócio? } \\
\text { ( ) Nenhuma } \\
\text { ( ) Planejamento }\end{array}$ \\
\hline
\end{tabular}

Perspectivas em Gestão \& Conhecimento, João Pessoa, v. 11, n. 2, p. 59-84, maio/ago. 2021. 


\begin{tabular}{|c|c|}
\hline $\begin{array}{l}\text { ( ) Falta de controle financeiro } \\
\text { ( ) Local/estrutura ruim } \\
\text { ( ) Falta de clientes } \\
\text { ( ) Falta de conhecimento sobre gestão do } \\
\text { negócio } \\
\text { ( ) Falta de crédito/empréstimo } \\
\text { ( ) Concorrência forte } \\
\text { ( ) Outra. Indique: }\end{array}$ & $\begin{array}{l}\text { ( ) Marketing } \\
\text { ( ) Compras/fornecedores } \\
\text { ( ) Controle financeiro } \\
\text { ( ) Acesso ao crédito/empréstimo } \\
\text { ( ) Clientes } \\
\text { ( ) Obrigações legais } \\
\text { ( ) Outra. }\end{array}$ \\
\hline $\begin{array}{l}\text { 12. Dentre os direitos e benefícios da } \\
\text { formalização como MEI, quais você não } \\
\text { conhece? } \\
\text { ( ) Direitos previdenciários (aposentadoria } \\
\text { por idade e por invalidez, auxílio doença, } \\
\text { auxílio maternidade, pensão por morte) } \\
\text { ( ) Emissão de nota fiscal } \\
\text { ( ) Tributação reduzida e fixa } \\
\text { ( ) Não é obrigatório possuir contador } \\
\text { ( ) Contratação de um funcionário } \\
\text { ( ) Preferência em licitações públicas } \\
\text { ( ) Utilizar a própria residência como } \\
\text { estabelecimento } \\
\text { ( ) Acesso à linhas de crédito específicas } \\
\text { ( ) Conheço todos os benefícios }\end{array}$ & $\begin{array}{l}\text { 13. Dentre as obrigações da formalização como } \\
\text { MEI, quais você não conhece? } \\
\text { ( ) Providenciar o alvará definitivo na prefeitura } \\
\text { no prazo máximo de } 180 \text { dias } \\
\text { ( ) Pagar o Documento de Arrecadação do } \\
\text { Simples Nacional (DAS) todo mês } \\
\text { ( ) Fazer a declaração do faturamento uma vez } \\
\text { por ano } \\
\text { ( ) Emitir nota fiscal nas vendas para outras } \\
\text { empresas } \\
\text { ( ) Realizar as obrigações trabalhistas, caso haja } \\
\text { um funcionário } \\
\text { ( ) Conheço todas as obrigações }\end{array}$ \\
\hline
\end{tabular}

Fonte: Elaborado pelos autores

Quadro 3 - Conhecimento sobre Instituições de Apoio

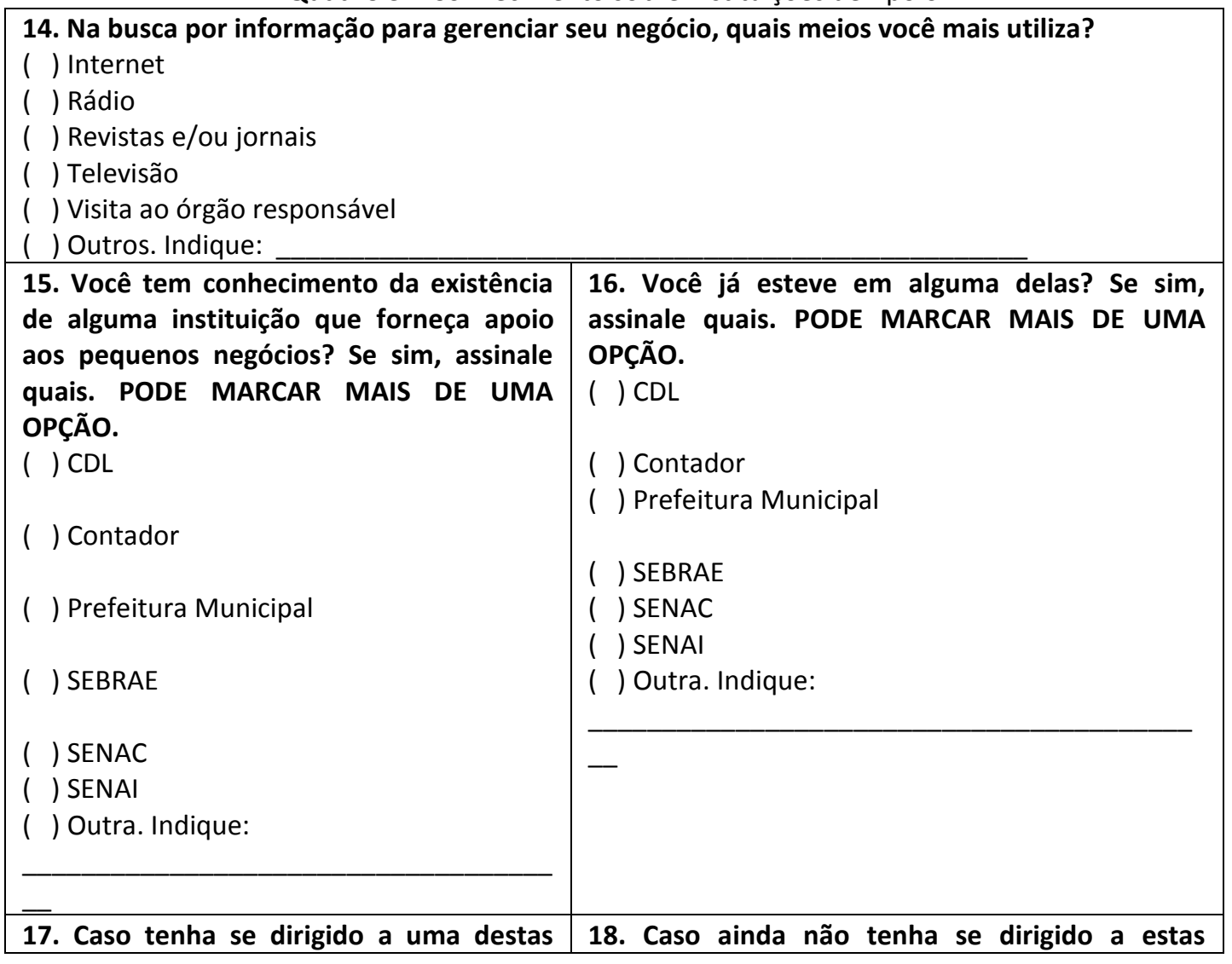

Perspectivas em Gestão \& Conhecimento, João Pessoa, v. 11, n. 2, p. 59-84, maio/ago. 2021. 


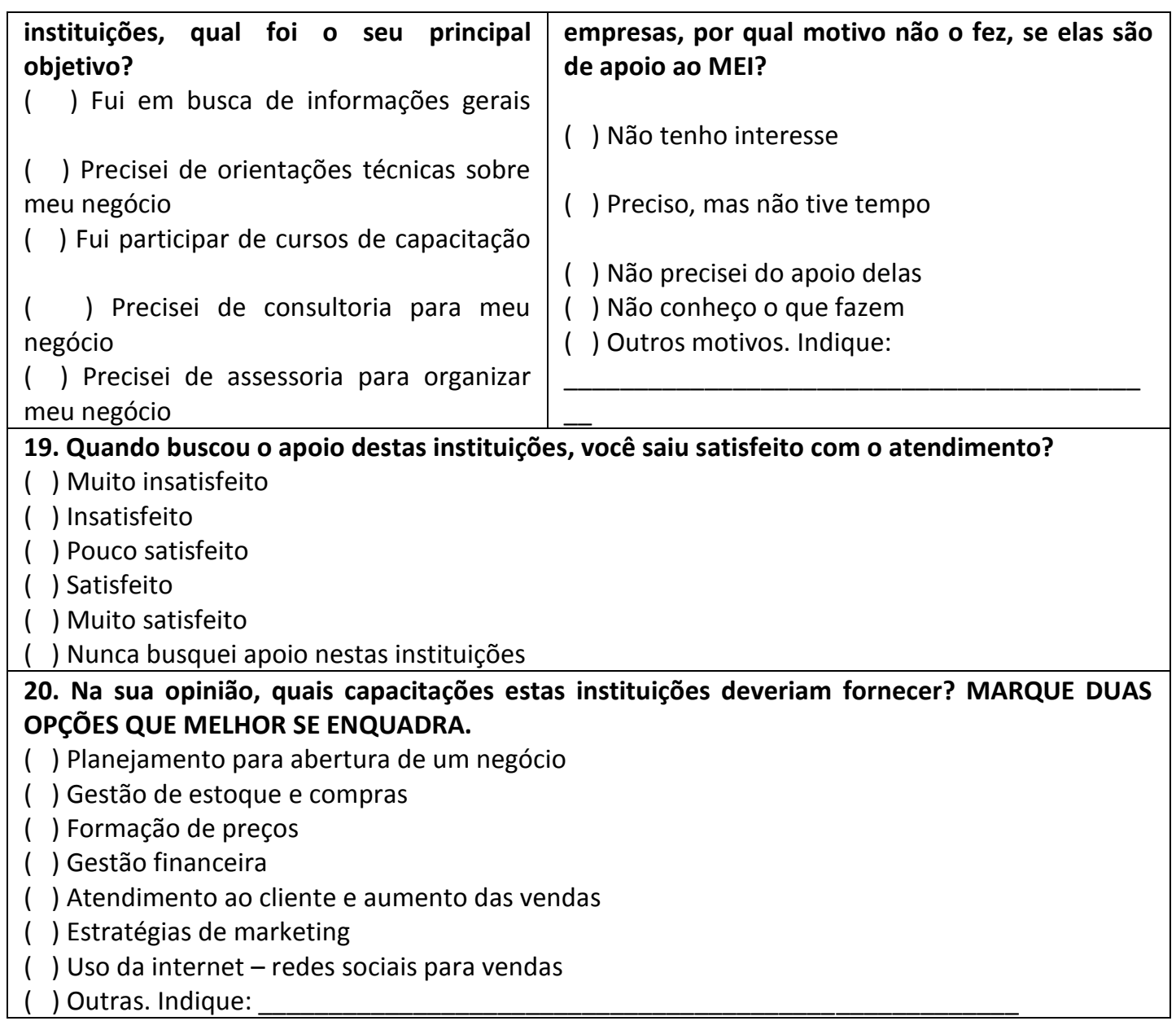

Fonte: Elaborado pelos autores

O município de São Mateus possui 6.838 Micro e Pequenas Empresas ativas e desse total $75,56 \%$ é representado pelo Microempreendedor Individual, sendo que dessa parcela $38,7 \%$ representam o setor de comércio, ou seja, 2.000. Os dados aqui presentes foram atualizados em fevereiro de 2018 e obtidos em SEBRAE/NA, com base na Receita Federal (ARAUJO, 2018).

A pesquisa de campo foi realizada entre os meses de julho e agosto de 2019, em horário comercial, entre $8 \mathrm{~h}$ às $18 \mathrm{~h}$, no centro da cidade, bem como nos bairros adjacentes regiões em que se encontram a maioria dos MEls do ramo de comércio. A aplicação se deu com 92 microempreendedores, os quais foram escolhidos por conveniência, sendo uma amostra não-probabilística.

\section{GESTÃO DE MICRO E PEQUENAS EMPRESAS}

Ao falar sobre pequenos negócios torna-se importante conhecer alguns conceitos acerca do termo empreendedor. Para Filion (1999), definir esse conceito é um desafio, pois existem diversos pontos de vista para estudá-lo. Filion (1999, p. 19) define:

O empreendedor é uma pessoa criativa, marcada pela capacidade de estabelecer e atingir objetivos e que mantém alto nível de consciência do ambiente em que vive, usando-a para detectar oportunidades de negócios. Um empreendedor que continua a aprender a respeito de possíveis 
oportunidades de negócios e a tomar decisões moderadamente arriscadas que objetivam a inovação, continuará a desempenhar um papel empreendedor.

Ainda, de acordo com Dornelas (2001, p. 37-38):

[...] o empreendedor é aquele que detecta oportunidade e cria um negócio para capitalizar sobre ela, assumindo riscos calculados. Em qualquer definição de empreendedorismo encontram-se, pelo menos, os seguintes aspectos referentes ao empreendedor: Iniciativa para criar um novo negócio e paixão pelo que faz. Utiliza os recursos disponíveis de forma criativa transformando o ambiente social e econômico onde vive. Aceita assumir os riscos e a possibilidade de fracassar.

Compreende-se por essas perspectivas que o empreendedor possui um conjunto de características: proatividade, criatividade, independência, disposição para correr riscos e perseverança para alcançar o planejado - essas particularidades nem sempre são intrínsecas ao indivíduo, contudo, podem ser desenvolvidas através do ensino e a pré-disposição para aprender; bem como pelas experiências vivenciadas por ele (SPUDEIT et al., 2019).

Segundo Longenecker et al. (2015), os empreendedores enxergam as necessidades do mercado e criam empresas para atendê-las, assumindo riscos, estimulando mudanças, inovação e desenvolvimento da economia. Concluem ainda que é fundamental acrescentar o gerenciamento às empresas sem sacrificar o espírito empreendedor, o que significa que a paixão pelo negócio deve sempre acompanhar o empresário, e que o papel de empreendedor, por sua vez, deverá adquirir características de administrador para obter sucesso.

Ao estudar um coletivo de empreendedores com seus respectivos negócios estabelecidos no mercado e atuantes em gestão, Guimarães Júnior (2019) constatou que eles são atores autogestores, pois realizam diversas tarefas, desde as mais simples até à tomada de decisões estratégicas e, ainda, possuem liberdade e autonomia para modificar a organização do trabalho, das atividades e de instituir o modelo de gestão que direcionará o negócio. Todavia, possuem uma rotina de incertezas, requerendo maior capacidade de planejamento e flexibilidade. Os empreendedores também relataram possuir dificuldades em aplicar os modelos de gestão apreendidos durante formações profissionais nas universidades e em suas experiências profissionais anteriores.

Diante disto, é importante considerar que o modelo de gestão empresarial aplicado às grandes empresas pode não ser eficaz, quando reproduzido nas pequenas empresas. Os conceitos são os mesmos, porém, devem ser adaptados à realidade existente em cada organização, pois cada uma apresenta suas singularidades e cultura(s), além de os desafios serem distintos.

Ainda nesse sentido, Neto, Marinho e Carvalho (2018) afirmam que o planejamento estratégico funciona como uma ferramenta para gestão organizacional, há uma grande dificuldade em sua aplicabilidade às micro e pequenas empresas, pois suas metodologias são elaboradas para as grandes organizações, tornando-se complexo quando aplicado nas unidades menores. E na visão de Fell e Dornelas (2020), as pequenas e médias empresas precisam estar atentas ao relacionar os fatores organizacionais (estrutura, estratégia, processos, pessoas e tecnologia) requerendo uma nova compreensão e esforço a este processo.

Para Longenecker et al. (2015), muitas empresas pequenas possuem uma fraqueza gerencial, parte delas existe somente para a sobrevivência do proprietário: funcionam, mas 
não necessariamente possuem uma gestão. Observa-se, ainda, que existe solução para essa fragilidade: a administração norteia o processo com qualidade.

De acordo com Drucker (1981), uma empresa só existe realmente na pessoa de seus administradores, entretanto, qualquer empresa, independente do formato jurídico, precisa de uma administração para funcionar. Drucker (1981, p. 10) também expõe que "[...] a administração de uma empresa não é uma questão de intuição ou capacidade nata; os elementos e requisitos de tal atividade podem ser analisados, organizados sistematicamente e transmitidos a qualquer pessoa com dotes intelectuais humanos normais". Entende-se pelo pensamento druckeriano que para garantir um bom desempenho das empresas, assim como evitar sua mortalidade, os empresários devem aprender os princípios e ferramentas da administração para gerirem seus negócios, e não ficarem fundamentados apenas em movimentos de experiências empíricas.

Para mais, é importante conhecer de modo geral algumas abordagens acerca da administração. Para Silva (2013, p. 6), “[...] administração é um conjunto de atividades dirigidas à utilização eficiente e eficaz dos recursos, no sentido de alcançar um ou mais objetivos ou metas da organização." Drucker (1981) colabora pontuando que a administração é uma prática, pois são as realizações que permanecem como metas e comprovam a eficácia da organização. Em vista disso, sem uma administração de qualidade os recursos podem não ser utilizados da melhor maneira e sequer atingir os objetivos da organização.

A administração possui quatro funções importantes, as quais fazem parte do processo de administrar e devem ser empregadas para alcançar os objetivos de uma determinada organização. Elas são apresentadas por Silva $(2013$, p. 10) da seguinte forma:

a) Planejamento: função na qual ocorre o estabelecimento de metas e objetivos, e a determinação de como os recursos serão utilizados; b) Organização: definição de departamentos e suas atividades, e alocação de recursos para cada um; c) Direção: envolve a condução das pessoas para que realizem suas atividades e alcancem os objetivos; d) Controle: é a função que analisa e melhora o desempenho da organização.

O ato de planejar é de fundamental importância para o desenvolvimento de uma organização. Direcionada por este planejamento, deve-se então organizar seus recursos para que efetivamente possa direcionar suas ações para o alcance dos resultados almejados. A correta direção de todos os envolvidos no processo se torna parte importante do processo. Por fim, o controle, produz a continuidade do ciclo, a permitir que a empresa possa evoluir e se manter em constante desenvolvimento.

Neste raciocínio, para uma melhor compreensão da gestão empresarial nos pequenos negócios e o papel desenvolvido pelo proprietário, é importante salientar alguns conceitos sobre o administrador. Dornelas (2001, p. 29) destaca o seguinte:

A abordagem clássica ou processual, com foco na impessoalidade, na organização e na hierarquia, propõe que o trabalho do administrador ou a arte de administrar concentre-se nos atos de planejar, organizar, dirigir e controlar. O principal divulgador desse princípio foi Henry Fayol, no início do século $\mathrm{XX}$, e vários outros autores reformularam ou complementaram seus conceitos com o passar dos anos.

Por outro lado, na visão de Chiavenato (1994, p. 27):

[...] é um profissional cuja formação é extremamente ampla e variada: precisa conhecer disciplinas heterogêneas (como matemática, direito, 
psicologia, sociologia, estatística etc.); precisa lidar com pessoas [...] que lhe estão subordinadas ou que estão no mesmo nível ou acima dele; precisa estar atento aos eventos passados e presentes, bem como às previsões futuras, [...]; precisa lidar com eventos internos e externos [...]; precisa ver mais longe que os outros.

Dessa forma, para ser considerado um administrador é necessário conhecer vários campos da ciência, mesmo que a princípio não pareça estar relacionado diretamente ao campo da ciência da administração como: conhecer um pouco do ser humano, das práticas da psicologia, da sociologia, estatística, da economia, da biologia, da física, da química e tantas outras. Para que se possa gerir, planejar, desenvolver, e ter total amplitude em eventos atuais e passados para definir o futuro, com menor probabilidade de erros, sem dúvidas o entendimento de todos estes campos é de fundamental importância para o conjunto necessário para alcançar o máximo de resultados possíveis.

Então, o administrador precisa ser um indivíduo aplicado, com noções amplas de conhecimento em gerir processos, como também saber usar as estratégias necessárias para atingir os bons resultados empresariais. Não é o caso de direcionar a atenção para empreendedor ou administrador, são conceitos distintos que se complementam. É preciso sonhar, mas também é muito importante transformar os sonhos em realidade fazendo com que perdurem.

Não é obrigatório possuir formação acadêmica para poder administrar o próprio negócio, contudo, quando se refere ao termo administrador considera-se que é necessário como um conceito mais amplo que é, obter por parte do envolvido, conhecimentos específicos. Como destacado por Chiavenato (1994), sabendo planejar, organizar, dirigir e controlar todos os seus recursos.

Diversos estudos (ALBUQUERQUE et al., 2018; GUERRA; TEIXEIRA, 2010; CÊRA; FILHO, 2003; SEBRAE, 2016a) apontam a gestão empresarial como um aspecto fundamental na sobrevivência de uma empresa. Um estudo realizado pelo SEBRAE, entre 2010 e 2014, confirma essa questão, apontando as seguintes características apresentadas pelas empresas inativas em comparação com as empresas ativas:

[...] entre as empresas que fecharam, há uma proporção maior de empresários que estavam desempregados antes de abrir o negócio, que tinham pouca experiência no ramo, que abriram o negócio por necessidade e/ou exigência de cliente/fornecedor, que tiveram menos tempo para planejar o negócio, que não conseguiram negociar com fornecedores nem conseguiram empréstimos em bancos, que não aperfeiçoavam seus produtos/serviços, que não investiam na capacitação da mão-de-obra, que inovavam menos, que não faziam o acompanhamento rigoroso de receitas e despesas, que não diferenciavam seus produtos e que não investiam na sua própria capacitação em gestão empresarial (SEBRAE, 2016a).

Guerra e Teixeira $(2010$,$) sintetizam como principais dificuldades para a sobrevivência$ dos pequenos negócios o acesso ao crédito e às novas tecnologias, pouco investimento em equipamentos sofisticados, propaganda, incapacidade de gestão estratégica, pouco poder de barganha com fornecedores, grande concorrência, baixo lucro e investimento em pesquisa e desenvolvimento.

Em um estudo com empresas da cidade de São Carlos-SP, Albuquerque et al. (2018, p. 199) fazem uma análise comparativa entre empresas de sucesso e as de insucesso, e revelam que:

Perspectivas em Gestão \& Conhecimento, João Pessoa, v. 11, n. 2, p. 59-84, maio/ago. 2021. 
Empresas de sucesso empregaram bem os fatores: tecnologia de informação, inovação em processo e marketing, baixa especialização das atividades, centralização das decisões, mecanismos de coordenação, comunicação informal, planejamento estratégico informal e planejamento formal de compras e financeiro.

Empresas de insucesso não empregaram bem os fatores: tecnologia de segurança, centralização das decisões, supervisão indireta, planejamento estratégico informal e planejamento de compras.

Para Cêra e Filho (2003), entretanto, a sobrevivência dos pequenos negócios inclui capacitação do empreendedor sobre técnicas administrativas adequadas à sua realidade, e não menos importantes, os programas políticos de apoio e de financiamento, porque não se deve considerar apenas o empreendedor como culpado pelo insucesso do negócio, mas todas as condições no contexto político-econômico.

Em suma, percebe-se que diversos aspectos, tanto do ambiente interno da empresa quanto do externo, impactam em sua sobrevivência ou mortalidade e a gestão empresarial apresenta diversas ferramentas que auxiliam o empreendedor/ administrador a driblar os desafios e alcançar os objetivos. Igualmente, é notória a importância da criação de políticas públicas eficazes de apoio aos pequenos negócios que forneçam recursos que atendam às suas reais necessidades e crie um ambiente propício para seu desenvolvimento.

\subsection{O Microempreendedor Individual e suas particularidades}

No Brasil encontra-se um grande número de micro e pequenas empresas que são responsáveis pelo fornecimento de grande parte dos serviços e produtos consumidos e pela maioria dos empregos gerados no país (SEBRAE, 2014). Em razão disso, foi instituída em 14 de dezembro de 2006 (Lei Complementar Federal 123/2006), a Lei Geral das Microempresas e Empresas de Pequeno Porte, a qual prevê o tratamento diferenciado e favorecido para estas, a fim de almejar: contribuir para o desenvolvimento e competitividade dos pequenos negócios no Brasil; reduzir a informalidade; aumentar a geração de emprego e melhor distribuição de renda, fortalecer a economia (SEBRAE, 2018).

Apesar da criação da Lei Geral das Microempresas e Empresas de Pequeno Porte em 2006, os autônomos ou ambulantes ainda tiveram dificuldades para se formalizarem, devido à burocratização. Pensando nisso, em 19 de dezembro de 2008, a Lei Geral teve alteração na sua redação pela Lei Complementar Federal 128/2008, criando o Microempreendedor Individual (MEI).

A Lei Complementar Federal 128/2008 define o conceito de MEl em seu artigo 18-A como o empresário que se enquadre na definição do art. 966 da Lei nำ10.406, de 10 de janeiro de 2002 - Código Civil, que tenha alcançado receita bruta, no ano-calendário anterior, de até $\mathrm{R} \$ 81.000,00$ (oitenta e um mil reais) e que seja optante pelo Simples Nacional. Assim, entende-se que o MEI deverá obter receita bruta anual de no máximo $\mathrm{R} \$ 81.000,00$, tendo proporcionalidade aos meses em atividade.

De acordo com a referida Lei, a pessoa que trabalha por conta própria pode se legalizar como pequeno empresário, desde que a atividade pretendida seja permitida para este enquadramento conforme a Resolução no 140 de 2018 do Comitê Gestor do Simples Nacional. Porém, não poderá ser sócio ou proprietário de empresa e é permitido a contratação de apenas um funcionário que receba um salário mínimo ou o piso da categoria. A pessoa que trabalha de carteira assinada, em regime CLT, pode se formalizar, entretanto, em caso de demissão perde o direito ao seguro desemprego, considerando que o MEl é uma fonte de renda.

Perspectivas em Gestão \& Conhecimento, João Pessoa, v. 11, n. 2, p. 59-84, maio/ago. 2021. 
Consoante ao Portal do Empreendedor, site do governo federal com gestão da Secretaria da Micro e Pequena Empresa, essa Lei traz para o MEl alguns direitos, dentre eles direito ao Cadastro Nacional de Pessoa Jurídica (CNPJ) sem custo e sem burocracia; não obrigatoriedade de serviços contábeis; a preferência em licitações públicas; a utilização da própria residência como estabelecimento; acesso à linhas de crédito específicas; e, por se enquadrarem no Simples Nacional, contribuem com valores reduzidos apenas para o Instituto Nacional do Seguro Social (INSS), e estes serão destinados à Previdência Social; Imposto Sobre Serviço (ISS) para o município e/ou Imposto sobre Operações relativas à Circulação de Mercadorias e sobre Prestações de Serviços de Transporte Interestadual e Intermunicipal e de Comunicação (ICMS) para o Estado. Assim, fica isento dos outros tributos e the é assegurado a aposentadoria por idade e por invalidez, o auxílio maternidade, o auxílio doença, o auxílio acidente, a pensão por morte e o auxílio reclusão.

Dentre esses direitos, a Lei também apresenta alguns deveres: providenciar a solicitação de alvará definitivo na prefeitura dentro de no máximo 180 dias; pagar o Documento de Arrecadação do Simples Nacional (DAS) todos os meses; uma vez ao ano deverá fazer uma declaração do seu faturamento para a Receita Federal do Brasil; deverá emitir nota fiscal nas vendas e prestações de serviços realizadas para qualquer pessoa jurídica sendo que, no caso de pessoa física, a emissão é necessária apenas quando solicitada pelo cliente; e outros (BRASIL, Lei Complementar no 128, 2008).

Ainda de acordo com essa Lei, a formalização poderá ser feita de forma gratuita no site do Portal do Empreendedor. E também poderá ser feita com a ajuda do Serviço Brasileiro de Apoio às Micro e Pequenas Empresas (SEBRAE) ou de empresas de contabilidade as quais são optantes pelo Simples Nacional e estão espalhadas pelo Brasil. Lembrando que toda atividade a ser exercida, mesmo na residência do profissional, necessita de autorização prévia da prefeitura, que nesse caso será gratuita.

A resolução do Comitê para Gestão da Rede Nacional para Simplificação do Registro e da Legalização de Empresas e Negócios - CGSIM no 36 de 2016, dispõe que se o MEI não tiver realizado a DASN-SIMEI nos dois últimos exercícios e esteja inadimplente quanto a todos os DAS mensais, terá o CNPJ suspenso pelo período de 95 dias e, no fim deste prazo, se não houver preenchido esses critérios, terá a sua inscrição definitivamente cancelada (BRASIL, 2016).

Desde a criação dessa classificação de porte de empresa, o número de registros vem aumentando. Segundo estatísticas do Portal do Empreendedor, até o dia 13 do mês de abril de 2019 o país já possuía mais de 8 milhões de empreendedores inscritos, tendo em média 855.000 registros por ano.

Conforme se pode constatar, a evolução anual do número de formalizações cresceu praticamente 1 milhão por ano a partir do ano de 2010, saindo em 2010 com 771.715 empreendedores inscritos para 7.738 .590 inscritos. Observou-se que no ano de 2018, praticamente não houve crescimento no número de registros, voltando a retomada no ano de 2019, isto pode ter ocorrido em consequência da baixa de 1,37 milhões de CNPJ de Microempreendedores Individuais que foram intimados em 2017, mas não regularizaram a sua situação até 26 de janeiro de 2018 (RECEITA FEDERAL, 2018).

Por virem ganhando mais espaço na economia do país, e através da sua formalização contribuírem para configurar um novo mercado de trabalho, necessitam de apoio para continuar e ampliar seus negócios. Com base nisso, criou-se em 2013 a Secretaria da Micro e Pequena Empresa ligada à Presidência da República que visa assessorar diretamente o Presidente da República especialmente na formulação, coordenação e articulação de políticas e diretrizes para o apoio à microempresa (BRASIL, Lei Complementar 12.792/2013). 


\subsection{Disponibilidade de apoio ao Microempreendedor Individual}

Denomina-se instituição de apoio todo e qualquer órgão que oferece recursos às micro e pequenas empresas que podem ser usufruídos pelo $\mathrm{MEI}$, com diversos auxílios de melhoria, como consultorias, treinamentos, etc. Não é incluído, no entanto, recursos financeiros, ou instituições financeiras neste estudo. Os recursos de apoio podem ser: fomento ao empreendedorismo; oferta de informação, orientação, consultoria, assessoria e capacitação nas áreas de gestão de empresas e atividades técnicas; programas de educação e treinamento para formação de mão de obra; associação de empresas, criando relacionamento entre elas.

Dessa forma, o Microempreendedor Individual pode encontrar um ambiente mais seguro para o crescimento de seu negócio. Assim, como afirma Albuquerque (1998), o Estado e a grande empresa não são os únicos agentes de desenvolvimento da economia, são também os gestores públicos locais e regionais; os empresários da localidade; as instituições de desenvolvimento regional, de capacitação, de pesquisa; em resumo, toda a sociedade, a fim de criar um ambiente em que os pequenos negócios possam ter acesso aos serviços de apoio - o que impulsiona o desenvolvimento econômico regional.

No município de São Mateus encontram-se alguns órgãos que fornecem apoio aos pequenos negócios, e que farão parte deste estudo, conforme pode ser observado na sequência:

Câmara de Dirigentes Lojistas (CDL): associação que foi fundada em 1983 e que oferece aos associados inúmeros serviços, dentre eles, o de proteção ao crédito, certificado digital, serviços advocatícios e benefícios como descontos em faculdades e planos de saúde (NARDOTO, 2016).

Contador: o MEl é dispensado de escrituração contábil, entretanto, ele poderá recorrer ou necessitar de tais serviços auxiliando-o em questões como contratação de funcionário, por exemplo. O MEI tem acesso a atendimento gratuito de assessoria contábil para a formalização e para a primeira Declaração Anual Simplificada da Microempresa Individual (DASN-SIMEI) (FENACON, 2015).

Prefeitura Municipal: criou a Lei Geral Municipal da Microempresa e Empresa De Pequeno Porte no âmbito do Município de São Mateus (Lei no 807/2009) e garante diversos benefícios, como por exemplo, preferência em licitações públicas e simplificação na emissão de alvarás e licenças.

Serviço Brasileiro De Apoio Às Micro E Pequenas Empresas (SEBRAE): atua exatamente no apoio à gestão empresarial, promoção da importância dos pequenos negócios e fomento do empreendedorismo. Os principais instrumentos de ação para com os clientes potencial empresário, MEI, ME e EPP - são: consultoria, capacitação e informação técnica. Esses instrumentos trabalham temas de gestão como empreendedorismo; mercado e vendas; pessoas; planejamento; inovação; organização; finanças; cooperação; e leis e normas (SEBRAE, 2020a).

Serviço Nacional De Aprendizagem Comercial (SENAC): de acordo com o site do SENAC, seu foco de atuação é o setor de comércio de bens, serviços e turismo. Através de cursos técnicos, cursos livres, graduação e pós-graduação (nas modalidades presencial e à distância), tem o intuito de formar e capacitar profissionais para esse setor, atuando em diversas áreas inclusive gestão e negócios, compreendendo técnicas organizacionais e de comercialização, economia, informática, marketing, logística, finanças e outros (SENAC, 2019).

Serviço Nacional De Aprendizagem Industrial (SENAI): instituição voltada para o desenvolvimento industrial e criada para qualificar profissionais para atuarem nesse setor. Possui programas de qualificação, que abrangem desde cursos de iniciação profissional, formação técnica destinada aos jovens aprendizes ou estudantes que estão cursando ou que já 
tenham cursado o ensino médio até o aperfeiçoamento profissional no qual os cursos buscam atualizar e ampliar a formação profissional. Essas capacitações aumentam a empregabilidade e geram renda tanto para o profissional, quanto para a empresa que o contrata (SENAI, 2019).

\section{RESULTADOS E DISCUSSÕES}

Ao entrevistar os 92 Microempreendedores Individuais do setor de comércio mateense, constatou-se inicialmente o perfil desses empresários, conforme segue.

\subsection{Perfil socioeconômico do Microempreendedor Individual}

No setor de comércio do município, entre os Microempreendedores Individuais, os homens empreenderam mais que as mulheres, eles representam $57 \%$ dos participantes da pesquisa, conforme mostra a Figura 1:

Figura 1 - Sexo dos Microempreendedores do comércio de São Mateus

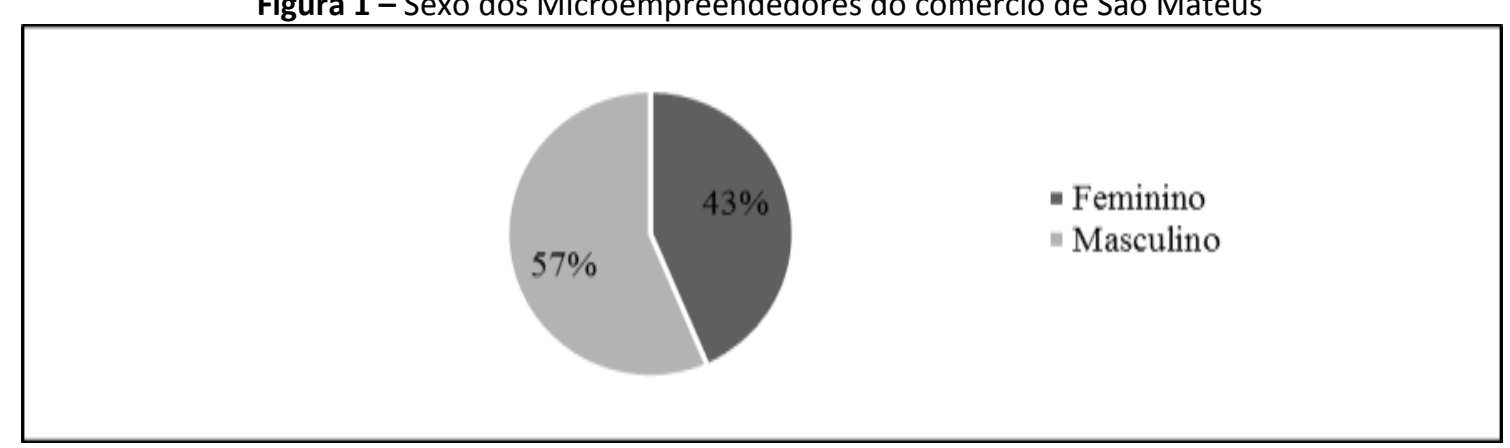

Fonte: Dados da pesquisa (2019)

GEM (2017) corrobora os resultados apresentados na Figura 1, ao afirmar que os homens brasileiros empreendem um pouco mais que as mulheres, considerando empreendimentos estabelecidos, porém, nos empreendimentos iniciais as mulheres superam os homens. Esta pesquisa potencializa os seguintes questionamentos: "seriam as mulheres menos persistentes na condução dos seus empreendimentos? Ou o ambiente para mulheres empreenderem ainda lhes é desfavorável e isso afeta a longevidade dos seus negócios?" No entanto, o quantitativo de homens e mulheres empreendedores são semelhantes, apresentando pequenas diferenças (GEM, 2017).

Pode ser observado na distribuição por faixa etária dos sujeitos participantes da pesquisa que, como Microempreendedor Individual, há mais adultos de faixa etária entre $30 \mathrm{a}$ 59 anos, que correspondem a 76\% dos negócios deste ramo, do que jovens de 18 a 29 anos e a faixa etária de 60 anos ou mais, conforme pode ser observado na Figura 2. Isso indica que as instituições da cidade devem estar atentas, utilizando métodos que atendam e alcancem esse público menor, não se esquecendo do público mais maduro que pode necessitar de uma atenção específica. 
Figura 2 - Faixa etária dos Microempreendedores do comércio de São Mateus

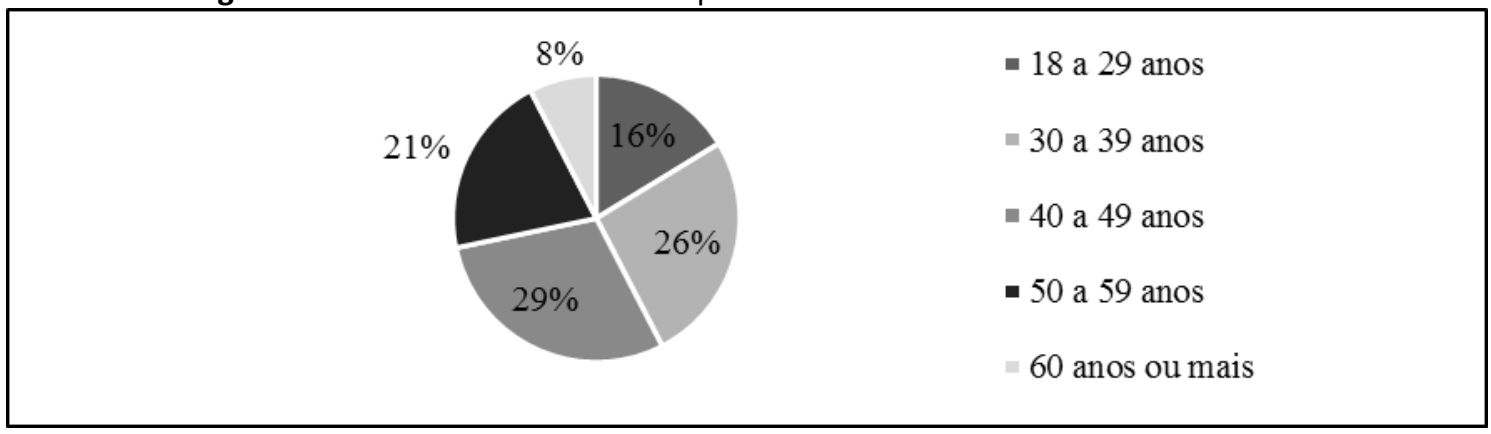

Fonte: Dados da pesquisa (2019)

Este perfil também coincide parcialmente com o da pesquisa do GEM (2017), que avalia o empreendedorismo de forma geral no Brasil: a faixa etária de 45 a 54 anos se destaca ao se tratar de donos de negócios já estabelecidos, existindo menos jovens com empreendimentos estabelecidos; apesar de haver mais jovens de 25 a 34 anos na criação de novos negócios (GEM, 2017).

Quanto ao grau de escolaridade, observa-se na Figura 3 que a maioria dos entrevistados, $63 \%$ deles, possui o ensino médio completo, e $14 \%$ possui ensino superior completo ou mais. Ainda assim, existe uma parcela significativa, de $18 \%$ deles que possuem apenas o ensino fundamental completo. Observa-se ainda que uma parte desses empreendedores (5\%), afirmaram não terem tido oportunidade de estudar. E essa falta de formação pode influenciar na busca por orientação, informação ou capacitação para gerenciar seu empreendimento.

Figura 3 - Grau de escolaridade dos Microempreendedores do comércio de São Mateus

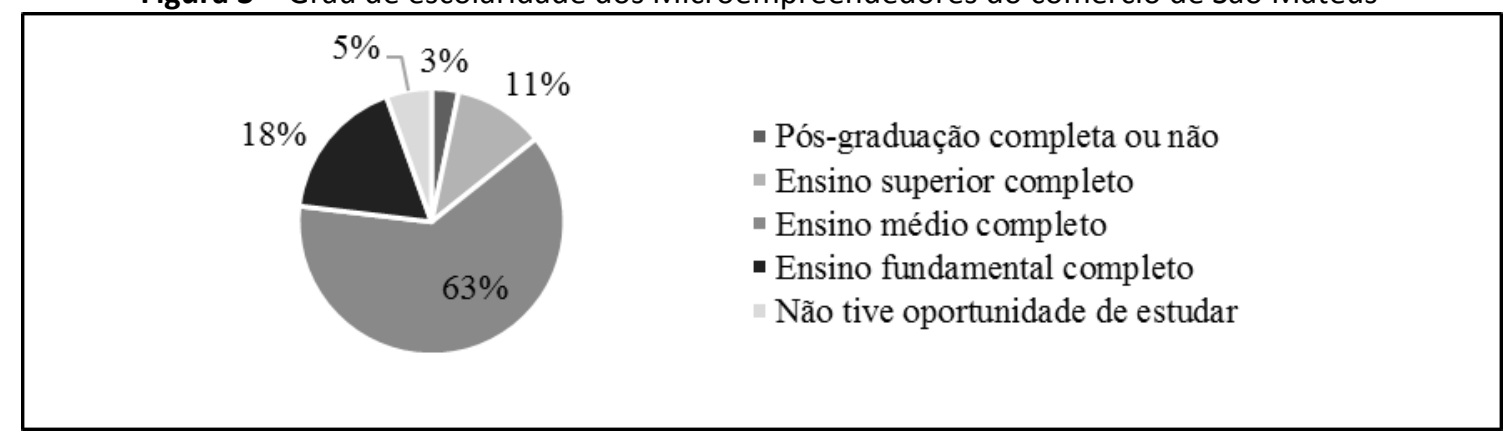

Fonte: Dados da pesquisa (2019)

Segundo o SEBRAE (2017), dos MEls de todos os setores no Brasil, uma parcela considerável $(43,4 \%)$ tem ensino médio completo ou incompleto e/ou técnico completo ou incompleto, seguido de ensino superior completo ou incompleto e/ou pós-graduação (33\%); ensino fundamental completo ou não (24\%); e $1 \%$ não tem instrução formal.

Estes dados divergem do estudo do GEM (2017), em que a maioria dos donos de negócios iniciais brasileiros possuem apenas o ensino fundamental completo (23,9\%). Dos negócios estabelecidos destaca-se o grupo de pessoas que não possuem sequer o ensino fundamental completo (22,5\%), seguido do grupo que possui ensino superior completo (17\%) (GEM, 2017).

Conforme delineado na Figura 4, observa-se que a maior parcela (70\%) dos MEls do ramo do comércio de São Mateus possui o faturamento médio mensal do negócio de até 4 salários mínimos. Há uma parcela de $11 \%$ que possui faturamento maior que 7 salários

Perspectivas em Gestão \& Conhecimento, João Pessoa, v. 11, n. 2, p. 59-84, maio/ago. 2021. 
mínimos. Neste caso, como o faturamento ultrapassa o permitido para este tipo de negócio, é necessário que o empresário procure um contador para realizar a migração do porte da empresa.

Figura 4 - Faturamento médio mensal do negócio dos Microempreendedores do comércio em São Mateus

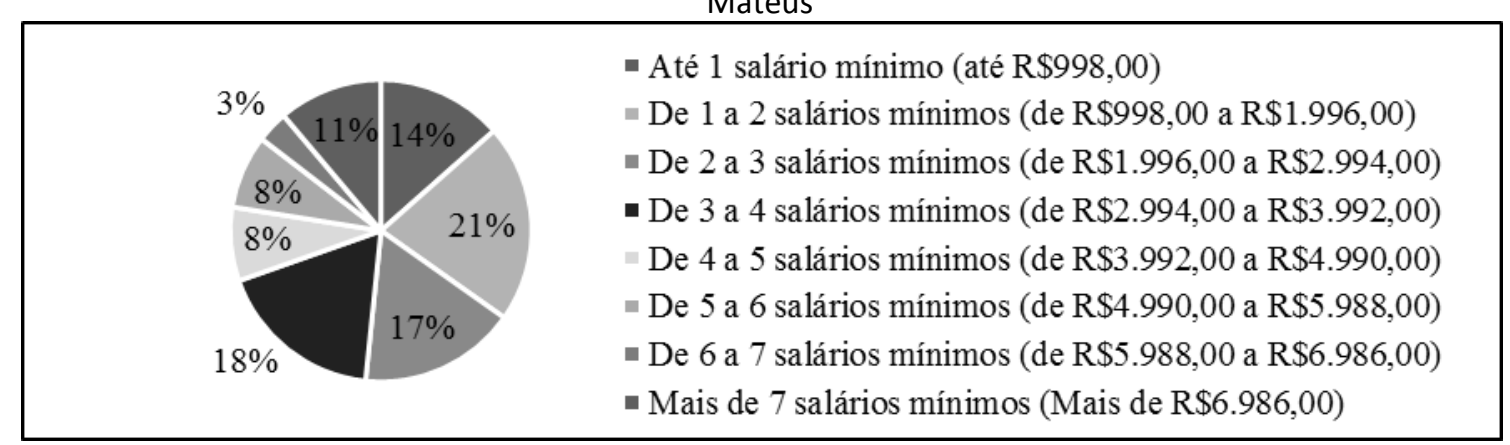

Fonte: Dados da pesquisa (2019)

O SEBRAE (2015) ao analisar o rendimento médio mensal dos pequenos negócios no Brasil, constatou-se que grande parte deles (36\%) é de até 1 salário mínimo (vigente em 2013), seguida de mais de 1 a 2 salários mínimos (25\%); mais de 2 a 3 salários mínimos (17\%); mais de 5 (12\%); e mais de 3 a 5 salários mínimos (10\%).

Também foi questionado aos entrevistados qual a renda média mensal de outra fonte que não seja o $\mathrm{MEl}$, e percebeu-se que a maior parte, $78 \%$, não possui outra fonte de renda. 0 faturamento como MEI pode se confundir com as finanças pessoais do empresário, exigindo um maior controle financeiro, uma vez que é sua única fonte de renda. Nesta situação, o empresário deve saber separar a pessoa física da pessoa jurídica, ou seja, os rendimentos da empresa não podem ser enxergados em sua totalidade como o salário do empresário, deve considerar as contas da empresa, como o pagamento de fornecedores e novos investimentos.

A nível nacional, $77 \%$ dos MEls também responderam que o seu negócio é a sua única fonte de renda. Em vista disso, infere-se o quão relevante é a formalização como MEI na geração de renda para o empreendedor e sua família (SEBRAE, 2017).

$\mathrm{Na}$ Figura 5 pode ser observado o tempo de maturidade dos MEls. Identifica-se nesse gráfico, uma quantidade relevante de Microempreendedores atuantes no mercado há mais de 6 anos, sendo $31 \%$ deles - estes merecem uma atenção específica no que tange a gestão do negócio para crescimento e migração do porte. Porém, verifica-se que $13 \%$ dos MEls ainda são jovens, com menos de um ano de existência, 20\% com tempo de vida entre 1 e 2 anos; 20\% com tempo de vida entre 3 e 4 anos e 18\% com tempo de vida entre 5 e 6 anos. Assim, 33\% destes MEls possuem tempo de vida menor do que dois anos. 
Figura 5 - Tempo de atuação como MEl do comércio em São Mateus

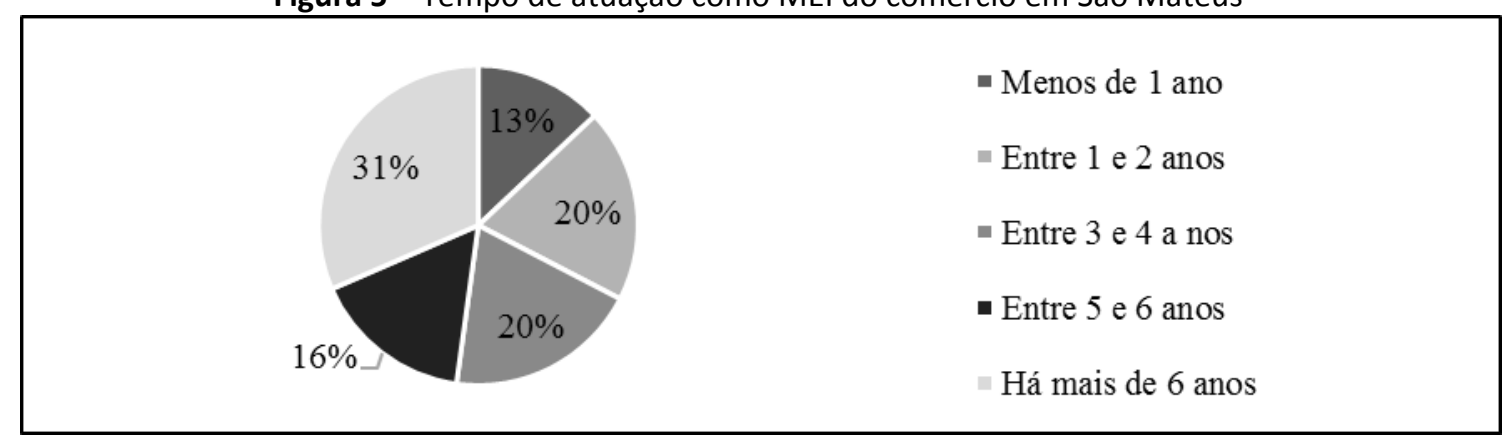

Fonte: Dados da pesquisa (2019)

A atuação no mercado como $\mathrm{MEI}$ durante tanto tempo ainda pode ser tema para investigações mais profundas a fim de buscar compreender as motivações da permanência neste porte, como, por exemplo, a má gestão que não permite o desenvolvimento do negócio ou até mesmo a comodidade trazida pela menor burocracia garantida pela legislação para manter a empresa.

\subsection{Gestão do negócio}

Foram respondidas pelos Microempreendedores Individuais questões que levaram à identificação das principais necessidades gerenciais enfrentadas por eles e estas serão apuradas nesta seção da pesquisa.

Questionados sobre a motivação para se tornar um microempreendedor, uma parcela notável, $45 \%$, respondeu que o motivo principal foi porque desejava ter o próprio negócio. Outra parcela, representando $18 \%$ dos entrevistados, respondeu que não havia outra oportunidade de trabalho - por isso optou por registrar-se como MEI, conforme mostra a Figura 6.

Verifica-se também, nesse gráfico, que $12 \%$ dos entrevistados se engajaram nesse negócio por vislumbrar ser uma boa oportunidade de crescimento profissional, outros $13 \%$ afirmaram que aderiram a esta forma de atividade devido à pressão dos clientes que o direcionaram, porém, $9 \%$ informaram que aderiram ao MEl apenas para sair da informalidade.

Figura 6 - Motivos da formalização como MEI do comércio em São Mateus

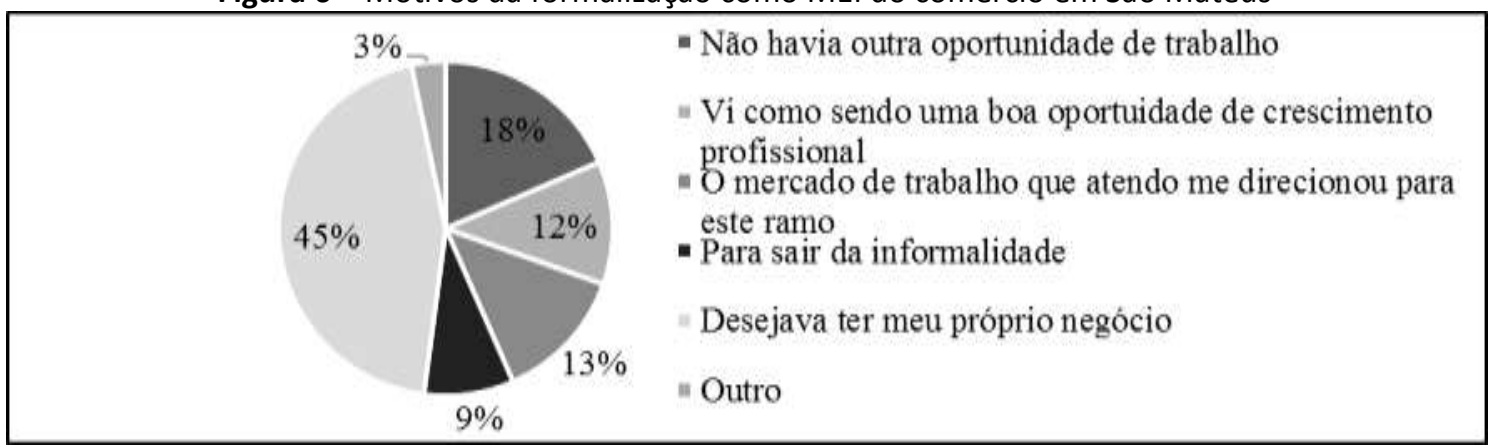

Fonte: Dados da pesquisa (2019)

Analisando a Figura 7, no que tange a principal dificuldade para abrir o negócio, 36\% dos respondentes apontaram que não tiveram nenhuma dificuldade, embora uma parcela de $31 \%$ apontou que a principal dificuldade foi a falta de capital, outra parcela de $15 \%$ pontuou

Perspectivas em Gestão \& Conhecimento, João Pessoa, v. 11, n. 2, p. 59-84, maio/ago. 2021. 
que a burocracia para formalização do negócio, $10 \%$ apontou a elaboração do planejamento do negócio, $2 \%$ a falta de experiência no ramo, $2 \%$ o desconhecimento do mercado, e $4 \%$ outra dificuldade não apontada na pesquisa.

Figura 7 - Principais dificuldades encontradas pelos MEls do comércio em São Mateus para abrirem o seu negócio

\begin{tabular}{|l} 
" Nenhuma \\
" Elaborar o planejamento do negócio \\
- A falta de experiência do ramo \\
- O desconhecimento do mercado \\
" Burocracia para formalização do negócio \\
- Falta de capital \\
- Outra
\end{tabular}

Fonte: Dados da pesquisa (2019)

Assim, verifica-se que com um apoio, por meio de políticas públicas, com disponibilização de linhas de crédito, apoio na logística para o planejamento e abertura do próprio negócio, $92 \%$ dos empreendedores seriam plenamente atendidos para iniciar seus negócios.

Ainda que uma parcela tenha respondido que a burocracia para formalização foi a principal dificuldade para abrir o negócio, conforme apresentado na Figura 7, poucos tiveram dificuldade, muita dificuldade ou dificuldade extrema quando questionados sobre a oficialização do negócio, apenas $15 \%$. Sendo que $85 \%$ responderam que não tiveram nenhuma ou tiveram pouca dificuldade. Sendo assim, entende-se que os MEls entrevistados possuem maiores dificuldades na abertura do que na formalização do negócio.

De acordo com a Figura 8, considerando que a questão é de múltipla escolha, quando questionados sobre quais as três maiores dificuldades na condução do negócio, os respondentes apontaram que a falta de crédito/empréstimo e a concorrência forte são os maiores entraves enfrentados por eles, com $35 \%$ e $33 \%$, respectivamente. Porém, observa-se que a falta de clientes (17\%), local/infraestrutura ruim (17\%) e a falta de conhecimento sobre gestão do negócio (16\%). Também são apontados por uma parcela expressiva dos MEls. Com um pouco menos de expressão, contudo um dado relevante, apareceram a falta de planejamento/organização (14\%) e a falta de controle financeiro (12\%).

Figura 8 - Maiores dificuldades encontradas na condução do negócio

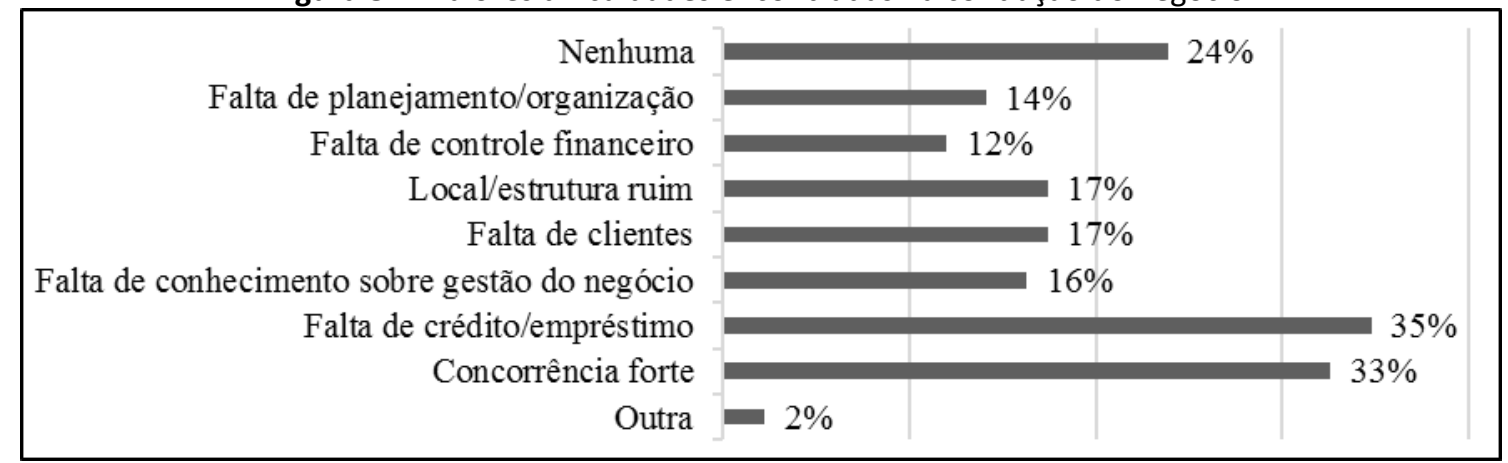

Fonte: Dados da pesquisa (2019) 
Assim, percebe-se que antes da disponibilização de linhas de crédito para este público, torna-se evidente a necessidade de fornecer capacitação nestas áreas citadas, pois, para sua própria sobrevivência é necessário fazer um bom planejamento e controle do seu negócio, bem como ter estratégias para atrair e fidelizar seus clientes e, precisa ter estrutura e local adequados para atendê-los.

Com relação à gestão do negócio, considerando a questão como de múltipla escolha, na Figura 9, em que cada participante apontou as três maiores dificuldades, observa-se que o acesso ao crédito/empréstimo se destacou, com $37 \%$ das indicações. Isso se deve ao fato de, provavelmente, o $\mathrm{MEI}$ ao adquirir sua mercadoria ele precise pagar à vista, para depois resgatar este investimento com as vendas - limitando ao empreendedor ampliar seu negócio.

Em segundo lugar, observa-se, na Figura 9, que as questões de marketing (24\%) é um problema sério enfrentado por eles, pois certamente não possuem meios e/ou não sabem como divulgar seu produto de forma correta. Compras/fornecedores e clientes ficaram empatados com $17 \%$ das indicações. Certamente a falta de dinheiro dificulta esse relacionamento, se não tem dinheiro, não consegue comprar... E se vende a prazo, ficará sem recursos para repor seu estoque.

Figura 9 - Maiores dificuldades encontradas na gestão do negócio

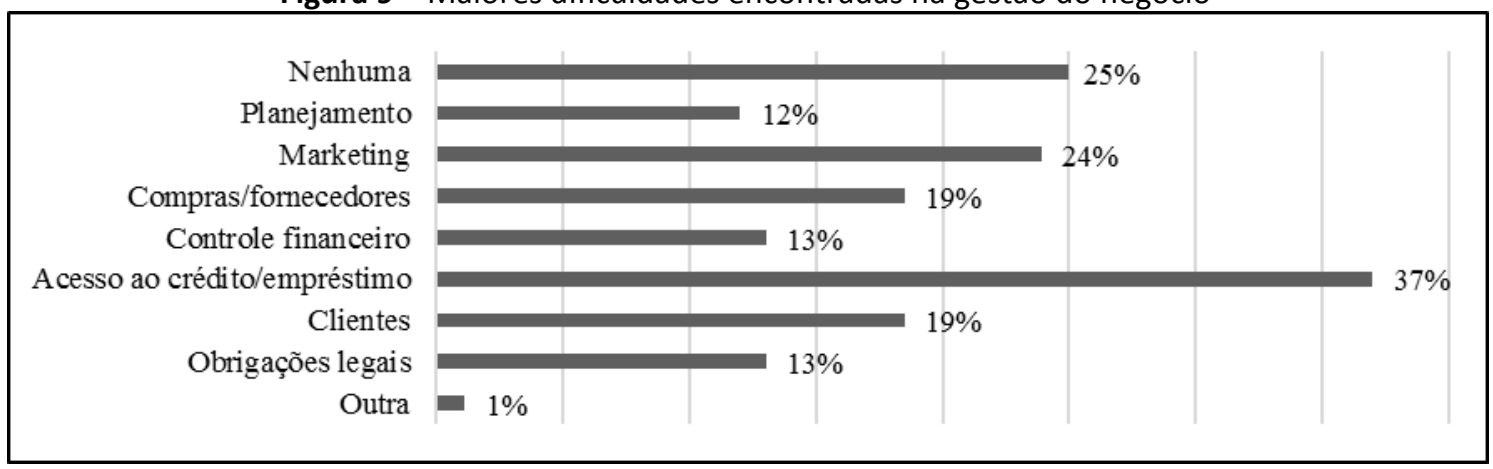

Fonte: Dados da pesquisa (2019)

Segundo o SEBRAE (2017), dos MEls de todos os setores, cerca de três a cada dez apontaram não ter dificuldade no processo de gestão do negócio (26\%); e entre os que declararam ter dificuldade (74\%), as mais mencionadas foram a conquista de clientes (31\%) e o crédito (7\%).

Ao serem questionados sobre quais direitos e benefícios da formalização como MEI eles não conhecem, verificou-se que embora $50 \%$ das respostas apontam que os entrevistados têm conhecimento de todos os benefícios, 39\% apontam não conhecer que possuem preferência em licitações públicas e $29 \%$ apontam que não têm conhecimento sobre acesso à linhas de crédito específicas.

Questionados sobre quais obrigações da formalização como MEl os entrevistados desconhecem, quase todas as respostas apontam que eles conhecem todas as obrigações, $83 \%$. Entretanto, $14 \%$ das respostas apontam desconhecimento sobre o alvará e $7 \%$ sobre emissão de nota fiscal nas vendas para outras empresas.

\subsection{Conhecimento sobre instituições de apoio}

O GEM (2017) aponta as principais recomendações de especialistas para melhorar o ambiente para se empreender no Brasil, sendo uma delas a educação e capacitação, com investimento de programas governamentais, com apoio às instituições de fomento ao empreendedorismo, incentivo ao empreendedorismo nas mídias de massa, inserção da

Perspectivas em Gestão \& Conhecimento, João Pessoa, v. 11, n. 2, p. 59-84, maio/ago. 2021. 
atividade empreendedora em ambientes escolares e maior aproximação entre pesquisa e tecnologia com empreendedores.

Entendendo a importância da educação e capacitação, foi questionado aos MEls entrevistados quanto ao seu conhecimento sobre as instituições de apoio aos pequenos negócios presentes no município e aos aspectos que influenciam na busca por informações gerenciais, conforme será apresentado nos próximos parágrafos desta subseção.

Ao buscar por informações para gerenciar o negócio, a maior parte dos entrevistados informou que recorre a internet e, em segundo plano, com 30\% das afirmativas informaram que visitam o órgão responsável. Dentre os que marcaram a opção outros, $4 \%$ das respostas mostram não buscar informação, $1 \%$ procura outro empresário, e $1 \%$ "boca a boca". Constatase então que os programas governamentais e instituições de apoio conseguem alcançar este público principalmente pela internet embora uma boa parcela ainda prefere se dirigir pessoalmente ao órgão responsável.

Na Figura 10 é apresentado o resultado das respostas dos entrevistados sobre quais das instituições que atuam como apoio ao MEl eles têm conhecimento, podendo responder mais de uma alternativa. Analisando esta figura, verifica-se que a maioria deles tem conhecimento da existência do SEBRAE, representando 93\% das respostas, seguido contador, $45 \%$, com $8 \%$ a CDL e $36 \%$ a Prefeitura Municipal. Uma parcela menor respondeu SENAC e SENAI. Vale salientar que todas estas instituições possuem unidades fixas no município de São Mateus.

Figura 10 - Instituições de apoio aos pequenos negócios conhecidas pelos MEls do comércio em São Mateus

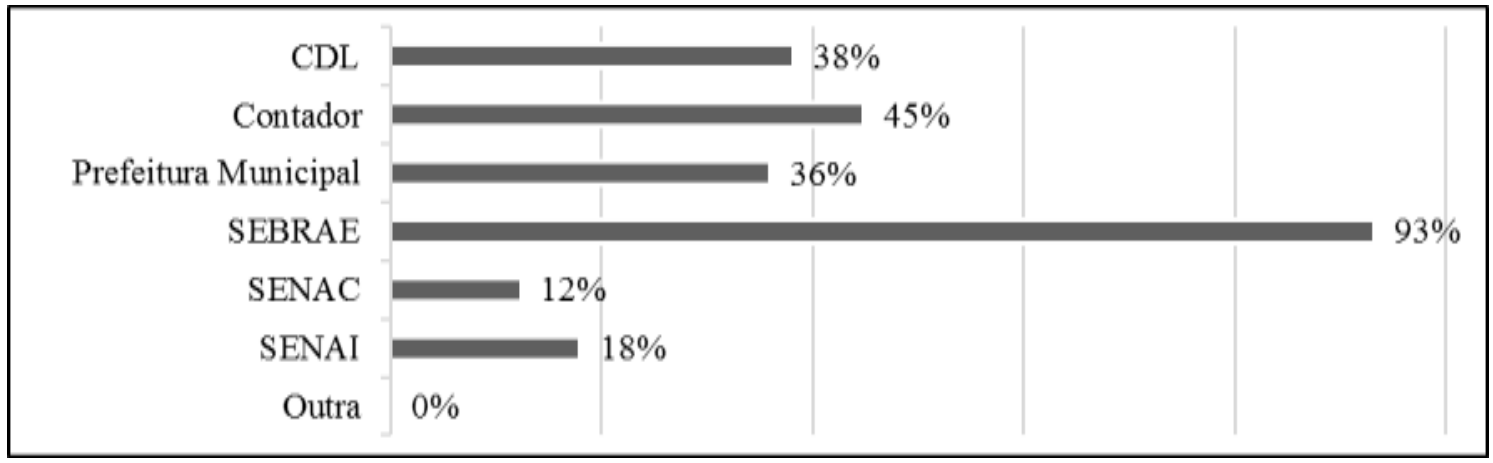

Fonte: Dados da pesquisa (2019)

Quando questionado aos entrevistados se já estiveram em alguma dessas instituições, podendo responder mais de uma opção, novamente a maioria respondeu SEBRAE $(79,1 \%)$, seguido do contador (32,6\%), Prefeitura Municipal (31,4\%) e CDL (20,9\%). Uma pequena parcela respondeu que já esteve no SENAI e SENAC, 9,3\% e 3,5\%, respectivamente. Portanto, essas instituições poderiam trabalhar mais a divulgação do seu trabalho para torná-lo mais acessível aos MEls.

Quando questionados sobre o principal objetivo para buscar essas instituições, a prevalência das respostas deu-se pela busca por informações gerais, representando $40 \%$; seguida de participação em cursos de capacitações, com 32\%; e a busca por orientações técnicas sobre o negócio obteve $14 \%$ das respostas. Provavelmente, aqueles que foram em busca de informações gerais devem ser aqueles que estavam iniciando suas atividades como MEl, mas observou-se que muitos foram já em busca de capacitação.

Percebe-se uma preocupação desse público em obter conhecimento para gerenciar o próprio negócio ao buscar essas instituições de apoio para se informar, orientar e capacitar. 
Ainda se tratando dos entrevistados que buscaram o apoio das instituições, a maioria, $79 \%$, responderam que saíram satisfeitos com o atendimento.

Identificou-se que $15 \%$ dos entrevistados não procurou nenhum destes órgãos para obter apoio institucional, em sua maioria, o motivo foi porque precisou, no entanto, não houve disponibilidade, representando $43 \%$ das respostas. Outra parcela representativa respondeu não ter precisado do apoio delas, representando 36\%. Não tiveram interesse ou não conhecem estas instituições, representou $14 \%$ deste grupo. Assim sendo, $57 \%$ deste grupo, ou seja, $8,7 \%$ dos entrevistados que ainda não procuraram estas instituições, conduzem seus negócios sem se preocupar com a gestão sustentável do empreendimento.

A Figura 11 mostra as respostas dos participantes da pesquisa quando questionados sobre quais capacitações estas instituições deveriam fornecer, podendo eles marcarem até duas opções. Verifica-se nesta figura que a opção mais demandada foi planejamento para abertura de um negócio, com $34 \%$, em seguida aparecem atendimento ao cliente e aumento de vendas e; estratégias de marketing com $33 \%$. O curso de gestão financeira obteve $30 \%$ das intenções e o uso da internet - redes sociais para vendas teve $28 \%$ de intenções. Uma parcela menor, com $13 \%$, respondeu formação de preços e outra, com $11 \%$, respondeu gestão de estoque e compras.

Assim, infere-se que existe uma demanda reprimida de capacitação, pois quase todos os cursos tiveram razoável intenção de demanda. Desta forma, é preciso que se disponibilizem tais cursos, todavia, é importante que eles sejam divulgados de forma ampla aos possíveis demandadores.

Figura 11 - Capacitações que as instituições deveriam fornecer, apontadas pelos MEls do comércio em São Mateus

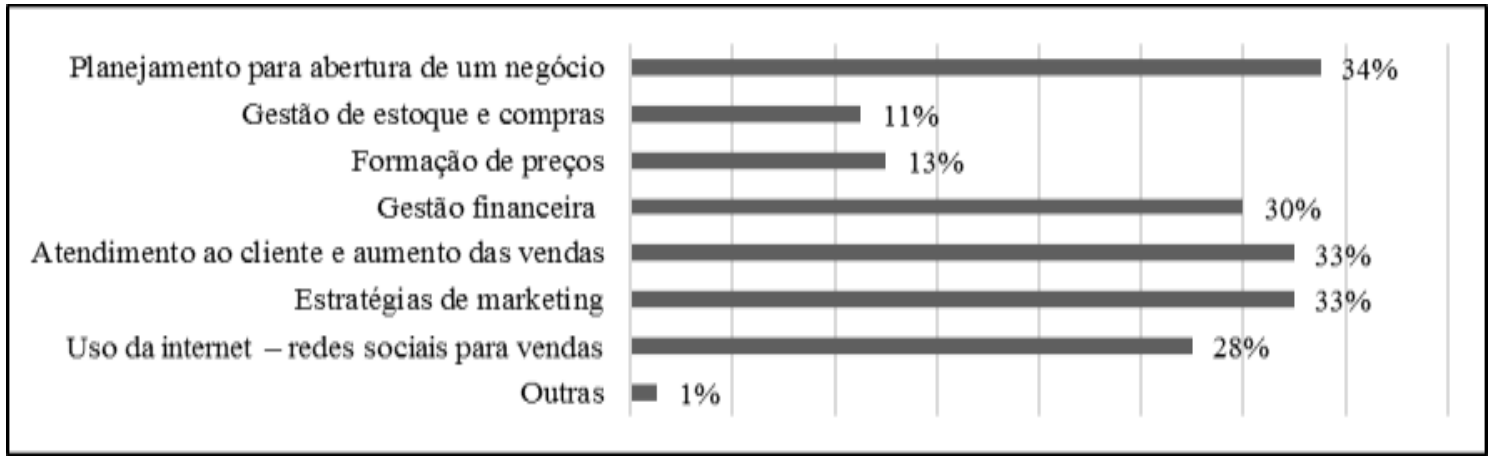

Fonte: Dados da pesquisa (2019)

Constata-se o reconhecimento dos empresários de que todas as áreas da gestão do negócio apontadas na pesquisa necessitam de capacitação. De acordo com um estudo do SEBRAE (2017), os MEls apontaram como maior necessidade de capacitação em controle financeiro, em orientação para crédito, em marketing, e em qualidade de produto ou serviço.

\subsection{Soluções para o enfrentamento das dificuldades encontradas}

Como discorrido na abordagem conceitual, a administração de um negócio é a solução fundamental para sua sobrevivência e desenvolvimento. Diante disto, trazemos à esta sessão do trabalho algumas propostas de intervenção para o enfrentamento das principais dificuldades apontadas pelos respondentes.

A burocracia foi apontada como uma das dificuldades para abertura do negócio, porém espera-se que esta dificuldade seja diminuída, pois, após a realização da pesquisa de campo, foi sancionada a Lei da Liberdade Econômica, № 13.874, em 20 de setembro de 2019, 
visando diminuir a burocracia para abertura de empresas, inclusive micro e pequenos negócios, não serão exigidos alvará e licenças de empresas que exerçam atividade de baixo risco, sendo estas definidas pelo Poder Executivo na ausência de regras específicas estaduais, distritais ou municipais (BRASIL, Lei no 13.874, 2019).

Quanto ao planejamento para abertura do negócio, uma ferramenta importante que auxiliará o empreendedor é o plano de negócios, para traçar os objetivos e o caminho a ser percorrido para serem alcançados, com o intuito de identificar a viabilidade da ideia, fazendo um retrato do mercado, do produto, dos clientes, dos concorrentes, dos fornecedores e dos pontos fortes e fracos do negócio (SEBRAE, 2019).

Acerca da gestão financeira é importante identificar as receitas e despesas, projetando todas as entradas e pagamentos a serem realizados a curto e longo prazo e tendo controle das contas a receber, o que ajudará a diminuir a inadimplência e a ter dinheiro no caixa para pagamento dos fornecedores. Estes controles podem ser feitos de forma simples, em um caderno ou com auxílio de programas (software) (ALBUQUERQUE; ESCRIVÃO FILHO; TERENCE, 2016).

Também foram apontadas dificuldades quanto ao marketing, a concorrência e aos clientes, nas quais é possível perceber uma correlação: quando estabelecidas estratégias de marketing, considera-se o que pode agregar valor ao produto, sendo necessário traçar o perfil dos clientes para atender suas necessidades e conseguir fidelidade, que por consequência, a clientela não procurará a concorrência - já que suas demandas serão atendidas por esta empresa.

Ressalta-se que é importante o empresário analisar sobre o que pode ser oferecido ao cliente e sobre o preço que ele está disposto a pagar, sempre considerando o preço da concorrência. Analisar também o ponto de venda, a localização, e a estrutura; a comunicação com o cliente a respeito de ofertas (que pode ser realizada, inclusive pelas redes sociais); bem como as estratégias de vendas: ponto de venda, sacolas ou por telefone (ALBUQUERQUE; ESCRIVÃO FILHO; TERENCE, 2016).

Com relação às compras de fornecedores, para que não haja dependência de apenas um fornecedor e o risco de não ocorrer a entrega do produto, é importante criar um cadastro de fornecedores por produto, devendo-se analisar diversos fatores para escolha destes fornecedores, como, distância, referências, custo do frete, qualidade, capacidade de fornecimento, preço, prazo, e forma de pagamento e entrega (SEBRAE, 2020b).

Em suma, salienta-se que os empresários mateenses podem buscar as instituições de apoio presentes no município para auxiliá-los nas dificuldades apontadas, bem como em capacitar-se em outras áreas da gestão, seja por meio de consultoria, assessoria, capacitações ou treinamentos.

\section{CONSIDERAÇÕES FINAIS}

A presente pesquisa de campo realizada no município de São Mateus-ES buscou contribuir com informações que possam auxiliar a gestão empresarial dos Microempreendedores Individuais do setor de comércio, levantando o perfil desse público, suas necessidades gerenciais e suas percepções acerca de instituições de apoio presentes no município.

Nesse contexto de produção da pesquisa, consonante aos objetivos propostos, foi possível traçar um perfil para o MEI mateense, no qual encontram-se mais adultos entre 30 a 59 anos, destacando-se a participação dos homens, embora com pouca diferença da participação das mulheres; em sua maioria possui o ensino médio completo; apresentam rendimento médio mensal de menor que 4 salários mínimos e não possuem outra fonte de 
renda além dessa referida; constatou-se também que a maioria é envolvida por empreendimentos novos - atuam no mercado entre 1 e 4 anos, mas existe, ainda sim, uma parcela considerável que atua há mais de 6 anos.

Foram identificadas as principais necessidades gerenciais enfrentadas por esses empresários, sendo que boa parte se tornou MEI porque desejava ter o próprio negócio, ainda que muitos deles apontassem que não havia outra oportunidade de trabalho. A maioria dos respondentes apontou que não tiveram dificuldade para abrir o negócio e nem para oficializálo, entretanto, mesmo que a legislação diminua a burocracia para este tipo de negócio, ela foi apontada como um fator que muito dificulta a abertura da empresa.

Outra adversidade pontuada pelos respondentes é a falta de capital, de crédito e empréstimo - tanto na abertura quanto na condução do negócio, sendo questionável a facilidade no acesso ao crédito para as pequenas empresas, também assegurado pela legislação. Ressalta-se que a forte concorrência também foi apontada por uma parcela significativa dos entrevistados como uma dificuldade à condução do negócio.

Quanto à gestão do negócio, além do acesso ao crédito e empréstimo, as dificuldades mais apontadas foram marketing; compras e fornecedores; e clientes. Foi possível perceber também que os microempreendedores entrevistados estão cientes dos direitos e obrigações adquiridos com a formalização. Contudo, todas as dificuldades expostas merecem atenção das instituições de apoio na criação de programas e capacitações voltados para suprir essas necessidades.

Notou-se que a internet é o principal meio utilizado na busca por informações gerenciais, embora ir ao órgão responsável também é preferível pelos entrevistados. Dentre as instituições apontadas, o SEBRAE é a mais conhecida e mais procurada pelos MEls com os principais objetivos de buscar informações gerais e cursos de capacitação, evidentemente pelo seu trabalho específico com as micro e pequenas empresas. Entretanto, as outras instituições são importantes em diversos aspectos desde a abertura até o desenvolvimento do negócio, e estas poderiam se apresentar mais acessíveis a esse público.

Diversas áreas da gestão do negócio foram reconhecidas pelos próprios empresários como necessidade de capacitação, dentre elas o planejamento para abertura do negócio, atendimento ao cliente e aumento das vendas, estratégias de marketing, gestão financeira e uso da internet - redes sociais para vendas.

Constatou-se que a falta de conhecimento teórico para empreender o negócio pode influenciar na sobrevivência da empresa, contudo, observou-se que no município de São Mateus/ES existem o SEBRAE e outras instituições que apoiam os pequenos negócios; e que podem subsidiar esse tipo de saber técnico ao $\mathrm{MEI}$.

Diante do exposto, averígua-se que os Microempreendedores Individuais do setor de comércio do município de São Mateus são adultos, com poucos jovens empreendedores; possuem um bom nível de escolaridade, o que influencia em sua busca por informações que auxiliam na gestão; conhecem os direitos e deveres da formalização, e as instituições de apoio, como o SEBRAE, o que evita o surgimento de problemas, e quando acontece, ele busca solucioná-los. Para a maioria dos sujeitos participantes da pesquisa, o MEl é a sua única fonte de renda, o que mostra a importância do empreendedorismo na economia, bem como merece uma atenção especial na criação de políticas públicas para que se mantenham sustentáveis. Contudo, necessitam de auxílio na abertura do negócio principalmente para que estejam bem estruturados e amparados e que tenham menos dificuldades na condução e gestão do negócio.

Com isto, recomenda-se que as instituições de apoio ao empreendedorismo adquiram uma nova visão para trabalhar e alcançar esse público, bem como a criação de políticas públicas com enfoque nas necessidades apresentadas na pesquisa. Sugere-se também que os 
Microempreendedores Individuais busquem não apenas registrar uma empresa, mas sim, aprender, adquirindo conhecimento para aprimorar seus negócios.

Esta investigação apresenta algumas limitações em relação a amostra, pois nem todos os empresários abordados estavam dispostos a responder as questões e nem todos os MEls possuem ponto comercial que facilitem a sua identificação: alguns trabalham em casa ou de porta a porta, por exemplo. Outro ponto delicado é que diversos ambulantes abordados para aplicação da pesquisa atuavam na informalidade, ou seja, não possuíam registro como $\mathrm{MEI}$, sendo desconsiderados à coleta de informações para a amostragem. No entanto, tais fragilidades são entendidas como dados muito importantes para se conceber o perfil do MEI mateense.

A pesquisa em tela foi realizada com um considerável grupo de MEls do setor de comércio local, todavia, as reflexões aqui presentes podem ser continuadas: por isso, sugerese que outras pesquisas, dentro das concepções de administração aqui defendidas, sejam conduzidas para que se conheça mais afundo o perfil traçado aqui dos microempreendedores do município de São Mateus e adjacências.

\section{REFERÊNCIAS}

ALBUQUERQUE, A. F.; ESCRIVÃO FILHO, E.; TERENCE, A. C. F. Aspectos funcionais associados à mortalidade da Pequena empresa: fatores relevantes de operações, finanças e marketing no varejo de vestuário. EGEPE - Encontro de Estudos sobre Empreendedorismo e Gestão de Pequenas Empresas. 9., 2016, Passo Fundo/RS. Anais... Passo Fundo, 2016, p. 1-16.

ALbuQuerque, A. F.; FILHO, E. E.; NAGANO, M. S.; TERENCE, A. C. F. Os aspectos organizacionais e a mortalidade da pequena empresa: descrição dos fatores relevantes no setor de varejo de vestuário. GEPROS. Gestão da Produção, Operações e Sistemas, Bauru, Ano 14, no 3, jul-set/2018, p. 176-209.

ARAUJO, M. Dúvida - MEl. Mensagem recebida por vivian.hannah18@gmail.com em 22 de fev. 2018.

BORGES, R. P.; OLIVEIRA, D. M. Sobrevivência e mortalidade das micro e pequenas empresas: estudo dos fatores determinantes e condicionantes. Enciclopédia Biosfera, Centro Científico Conhecer, Goiânia, v.10, n.19, p.506-512, 2014.

BRASIL. Lei Complementar no 123, de 14 de dezembro de 2006. Institui o Estatuto Nacional da Microempresa e da Empresa de Pequeno Porte [...]. Disponível em: http://www.planalto.gov.br/ccivil 03/leis/lcp/lcp123.htm. Acesso em: 25 set. 2017.

BRASIL. Lei Complementar no 128, de 19 de dezembro de 2008. Altera a Lei Complementar no 123, de 14 de dezembro de 2006, altera as Leis nos 8.212, de 24 de julho de 1991, 8.213, de 24 de julho de 1991, 10.406, de 10 de janeiro de 2002 - Código Civil, 8.029, de 12 de abril de 1990, e dá outras providências. Disponível em: http://www.planalto.gov.br/ccivil 03/leis/lcp/lcp128.htm. Acesso em: 27 set. 2017.

BRASIL. Lei no 12.792, de 28 de março de 2013. Altera a Lei no 10.683, de 28 de maio de 2003, que dispõe sobre a organização da Presidência da República e dos Ministérios, criando a Secretaria da Micro e Pequena Empresa [...]. Disponível em: 
http://www.planalto.gov.br/ccivil 03/ Ato2011-2014/2013/Lei/L12792.htm. Acesso em: 16 nov. 2019.

BRASIL. Lei no 13.874, de 20 de setembro de 2019. Institui a Declaração de Direitos de Liberdade Econômica. Disponível em: http://www.planalto.gov.br/ccivil 03/ ato20192022/2019/lei/L13874.htm. Acesso em: 01 nov. 2019.

BRASIL. Resolução no 36, de 02 de maio de 2016. Dispõe sobre o procedimento de cancelamento de inscrição de microempreendedor individual - MEI inadimplente. Disponível em:

http://www.mdic.gov.br/images/resolucoesdrei/Resoluo 36 alterada pelas Resolues 39 43 - 44 verso fev19.pdf. Acesso em: 16 nov. 2019.

CÊRA, K.; FILHO, E. E. Particularidades de gestão da pequena empresa: condicionantes ambientais, organizacionais e comportamentais do dirigente. EGEPE - Encontro de Estudos sobre Empreendedorismo e Gestão de Pequenas Empresas. 3., 2003, Brasília. Anais [...]. Brasília: UEM/UEL/UnB, 2003, p. 796-812.

DORNELAS, J. C. A. Empreendedorismo: transformando ideias em negócios. Rio de Janeiro: Elsevier Editora Ltda, 2001.

DRUCKER, P. F. Prática da Administração de Empresas. 1. Ed. São Paulo: Pioneira, 1981.

FENACON. Institucional. Disponível em: http://www.fenacon.org.br/. Acesso em: 22 mai. 2019.

FELL, A. F. A.; DORNELAS, J. S. Gestão do conhecimento, tecnologia da informação e pequenas e médias empresas de serviços: Um estudo de casos múltiplos na Região Metropolitana do Recife. Perspectivas em Ciência da Informação, [S.I.], v. 25, n. 2, p. 29-55, jun. 2020.

FILION, L. J. Empreendedorismo: empreendedores e proprietários-gerentes de pequenos negócios. Revista de Administração, São Paulo, v. 34, n. 2, p. 05-28, abr./jun. 1999.

GEM (Global Entrepreneurship Monitor). Empreendedorismo no Brasil: Relatório executivo $2017 . \quad$ Disponível em: https://m.sebrae.com.br/Sebrae/Portal\%20Sebrae/Anexos/Relat\%C3\%B3rio\%20Executivo\%20 BRASIL web.pdf. Acesso em: 21 abr. 2019.

GIL, A. C. Métodos e técnicas de pesquisa social. 6. Ed. São Paulo: Atlas, 2008.

GUERRA, O.; TEIXEIRA, F. A sobrevivência das pequenas empresas no desenvolvimento capitalista. Revista de Economia Política. vol. 30, no 1 (117), p. 124-139, jan-mar/2010.

GUIMARÃES JÚNIOR, E. H. Como os empreendedores trabalham: uma leitura psicodinâmica da organização do trabalho de um grupo de empreendedores. Revista de Empreendedorismo e Gestão de Pequenas Empresas, [S.I.], v. 8, n. 1, p. 149-175, jan. 2019.

LONGENECKER, J. G. et al. Administração de Pequenas Empresas. 13. Ed. São Paulo: Cengage Learning, 2015. 
MARIA, J. P.; SOUZA, A. C. Micro empresário individual - empreendedorismo e realidade administrativa atual. Disponível em: http://repositorio.unesc.net/bitstream/1/2346/1/Jeferson\%20Przyvitowski\%20Maria.pdf. Acesso em: 22 mai. 2019.

NARDOTO, E. O. História, geografia e economia de São Mateus. São Mateus: ed. do autor, 2016.

NETO, J. V.; MARINHO, M. S.; CARVALHO P. S. Desafios da implantação do planejamento estratégico pela micro e pequena empresa. Revista Espacios. vol. 39. n. 33. 2018.

PREFEITURA MUNICIPAL DE SÃO MATEUS. Lei no 807/2009. Institui a Lei Geral Municipal da Microempresa e Empresa de Pequeno Porte e do Microempreendedor Individual [...]. Disponível em: https://www.saomateus.es.gov.br/uploads/legislacaoitens/Leis\%20Municipais $2009807 \quad 5 a 8$ a42f0-784f-49c4-8a04-7161e83a0acd.pdf. Acesso em: 22 mai. 2019.

RECEITA FEDERAL. Receita divulga relação de baixa de CNPJs - MEl. Disponível em: https://receita.economia.gov.br/noticias/ascom/2018/fevereiro/receita-divulga-relacao-debaixa-de-cnpjs-do-mei. Acesso em: 16 nov. 2019.

SEBRAE. Lei Geral da Micro e Pequena Empresa. 2018. Disponível em: https://www.sebrae.com.br/sites/PortalSebrae/sebraeaz/lei-geral-completa-10-anos-ebeneficia-milhoes-de-empresas,baebd455e8d08410VgnVCM2000003c74010aRCRD.

Acesso em: 22 mai. 2019.

SEBRAE.. Participação das Micro e Pequenas Empresas na Economia Brasileira. 2014. Disponível

em: https://www.sebrae.com.br/Sebrae/Portal\%20Sebrae/Estudos\%20e\%20Pesquisas/Participaca o\%20das\%20micro\%20e\%20pequenas\%20empresas.pdf. Acesso em: 22 mai. 2019.

SEBRAE. Os donos de negócio no Brasil: análise por faixa de renda (2003 - 2013). 2015. Disponível em: https://bibliotecas.sebrae.com.br/chronus/ARQUIVOS CHRONUS/bds/bds.nsf/5233f8a3bfff40 44344918255d387502/\$File/5772.pdf. Acesso em: 06 out. 2019.

SEBRAE. Panorama Sebrae - Janeiro/2019. 2019a. Disponível em: https://datasebrae.com.br/wp-content/uploads/2019/02/Panorama-Sebrae 012019.pdf. Acesso em: 22 mai. 2019.

SEBRAE. Perfil do Microempreendedor Individual 2017. 2017. Disponível em: https://datasebrae.com.br/wp-content/uploads/2018/03/Perfil-do-MicroempreendedorIndividual 2017-v10.pdf. Acesso em: 10 mar. 2019.

SEBRAE. Pesquisa de fornecedores. 2020b. Disponível em: http://www.sebrae.com.br/sites/PortalSebrae/artigos/pesquisa-defornecedores,ea7836627a963410VgnVCM1000003b74010aRCRD. Acesso em: 11 mar. 2020. 
SEBRAE. Quem 2020a. Domos. Disponível em: http://www.sebrae.com.br/sites/PortalSebrae/canais adicionais/conheca quemsomos. Acesso em: 05 abr. 2020.

SEBRAE. Sobrevivência das empresas no Brasil - 2016. 2016a. Disponível em: http://www.sebrae.com.br/Sebrae/Portal\%20Sebrae/Anexos/sobrevivencia-das-empresas-nobrasil-relatorio-2016.pdf. Acesso em: 22 mar. 2019.

SEBRAE. Tudo o que você precisa saber para criar o seu plano de negócio. 2019. Disponível em: $\quad$ https://www.sebrae.com.br/sites/PortalSebrae/artigos/como-elaborar-um-plano-denegocio,37d2438af1c92410VgnVCM100000b272010aRCRD. Acesso em: 01 nov. 2019.

SENAC. O que é o SENAC? Disponível em: http://www.es.senac.br/senac/index.html. Acesso em: 22 mai. 2019.

SENAI. Sobre o SENAI ES. Disponível em: https://senaies.com.br/. Acesso em: 22 mai. 2019.

SILVA, R. O. Teorias da Administração. São Paulo: Person Education Brasil, 2013.

SPUDEIT, D.; POLEZA, M.; MADALENA, C. DA S.; ROMEIRO, N. Formação para o empreendedorismo nos cursos de bacharelado e licenciatura em biblioteconomia, ciência da informação e gestão da informação no brasil. Perspectivas em Gestão \& Conhecimento, v. 9, n. 1, p. 232-247, jan./abr. 2019.

Recebido em/Received: 03/09/2020 | Aprovado em/Approved: 02/08/2021 